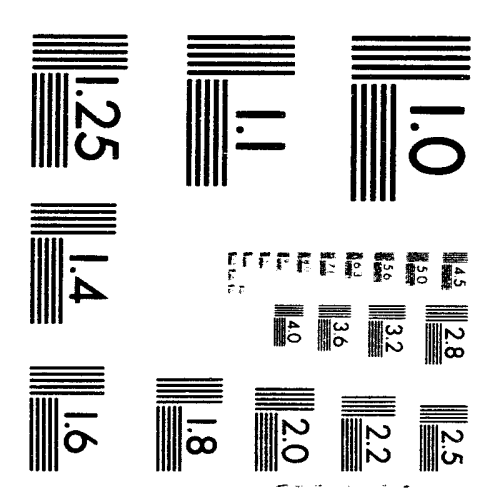



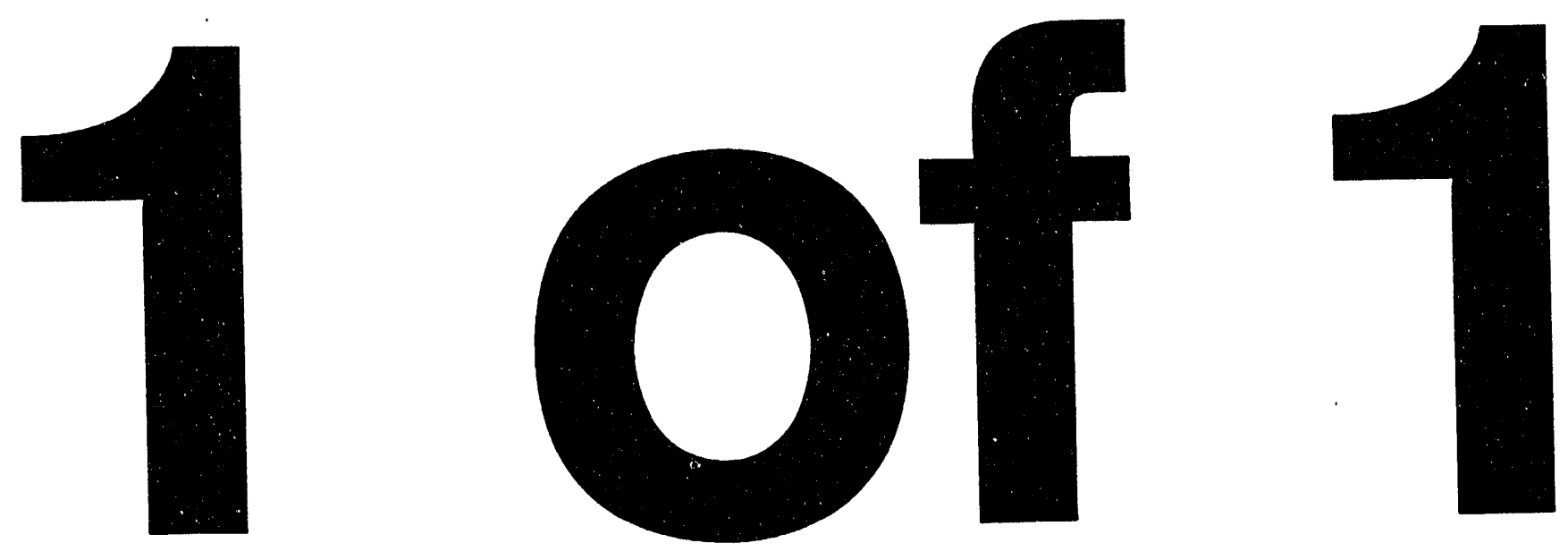
PNL-9060

UC-600

\title{
Qualitative Assessment of the Impacts of Proposed System Operating Strategies to Resident Fish Within Selected Columbia River Reservoirs
}

\author{
D. K. Shreffler \\ D. R. Geist \\ W. V. Mavros
}

January 1994

Prepared for

Bonneville Power Administration

Division of Fish and Wildlife

under a Related Services Agreement

with the U.S. Department of Energy

under Contract DE-AC06-76RLO 1830

Pacific Northwest Laboratory

Richland, Washington 99352
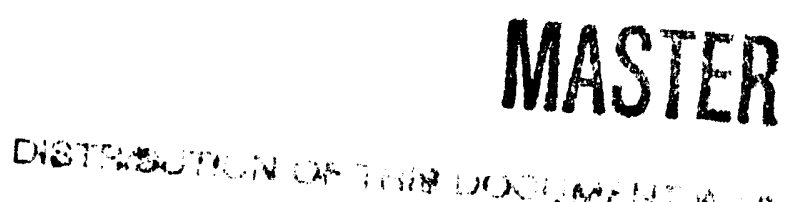


\section{SUMMARY}

The Bonneville Power Administration (BPA), Bureau of Reclamation (BOR), and U.S. Army Corps of Engineers (COE) are presently conducting the System Operation Review (SOR) for the Columbia River basin. The SOR began in 1990 and is expected to provide an operating strategy that will take into consideration multiple uses of the Columbia River system including navigation, flood control, irrigation, power generation, fish migration, fish and wildlife habitat, recreation, water supply, and water quality.

From a list of 91 alternatives for coordinated system operation, the SOR Management Team has selected 7 alternatives (a total of 21 options) for full-scale analysis. The objective of full-scale analysis is to determine a preferred alternative form of system operation that can be incorporated into an Environmental Impact Statement (EIS). To assist BPA and the SOR Management Team with this goal, the Pacific Northwest Laboratory (PNL) performed the following tasks:

1. a thorough review of relevant literature on resident fish populations within the following reservoirs and river reaches: Kinbasket Reservoir, Arrow Lakes, and Kootenay Lake in British Columbia, Canada; Flathead Lake, Montana; Clark Fork River below Cabinet Gorge Dam, Idaho; Pend Oreille River below Albeni Falls Dam, Washington; Lake Rufus Woods and the Columbia River below Chief Joseph Dam, Washington; the Mid-Columbia River below Wells, Rocky Reach, Rock Island, and Wanapum Dams, Washington; the Hanford Reach below Priest Rapids Dam, Washington; the Columbia River below Bonneville Dam, Washington and Oregon; and the Snake River below Hells Canyon Dam, Idaho and Washington. These areas were identified by the Resident Fish Work Group (RFWG) as having fish species of either economic or ecological significance;

2. interviews with individuals who have expertise on resident fish within these specified reservoirs and river reaches; and,

3. a qualitative assessment of impacts to resident fish that could potentially result from the seven proposed system operating strategies.

Based on our review of the literature and interviews with resident fish experts, we provide descriptions of each of the investigated reservoirs and river reaches. The descriptions focus on three distinct management goals for resident fish: biodiversity, species-specific concerns, and sport fisheries. In addition, this report provides a qualitative assessment of impacts to the resident fish within these reservoirs and river reaches from the seven alternative system operating strategies.

The system operating strategy (SOS) that is predicted to have the fewest impacts on resident fish is SOS-4 because it minimizes storage reservoir fluctuations while moving the Columbia River system closer to natural flow conditions at the run-of-river projects. 


\section{ACKNOWLEDGMENTS}

This work was funded by the Bonneville Power Administration (BPA) and would not have been possible without the support of Charlie Craig. Many members of the Resident Fish Work Group (RFWG), too many to list them all by name, provided input into this report. Jeff Laufle, David Statler, Janelle Griffith, Brian Marotz, Dan Kenny, Catherine Gee, Jack Stanford, Melo Maiolie, David Bennett, Kirk Truscott, Chris Carlson, Dennis Dauble, George McCabe, Steve King, Brad James, Ed Schriever, and Jim Chandler willingly shared their expertise on resident fish within particular reservoirs of the Columbia River system. We especially wish to thank the individuals who greatly improved this report through their editorial comments and suggestions--Dan Epstein, George McCabe, Ed Schriever, and David Bennett. Dan Epstein and Lance Vail helped us analyze the hydroregulated data that we were provided by BPA. Laura Gully assisted with the formatting and preparation of this report. Dennis Dauble provided a rigorous technical review. 


\section{CONTENTS}

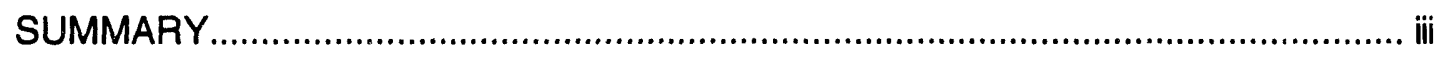

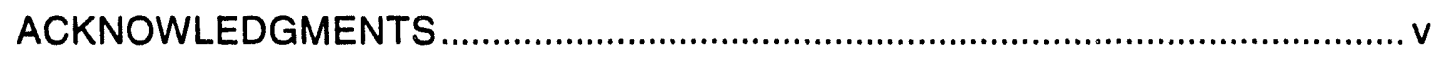

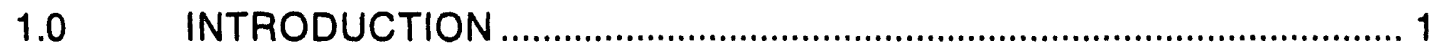

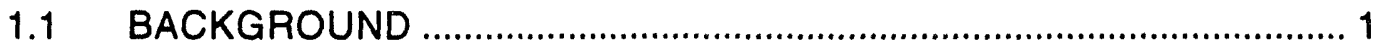

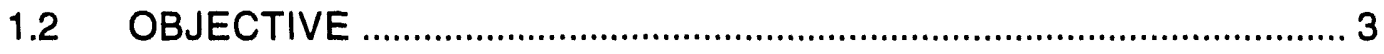

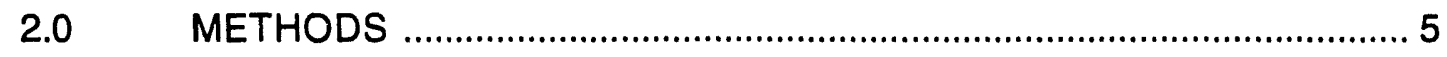

3.0 RESERVOIR DESCRIPTIONS ....................................................... 7

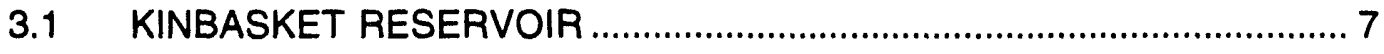

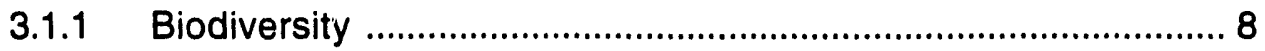

3.1.2 Species-Specific Concerns ................................................... 9

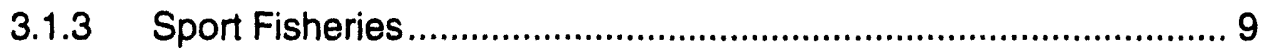

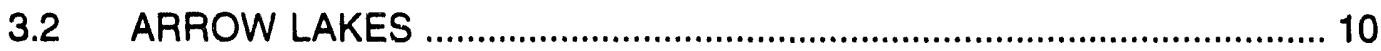

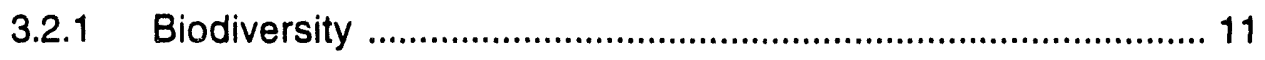

3.2.2 Species-Specific Concerns ................................................... 11

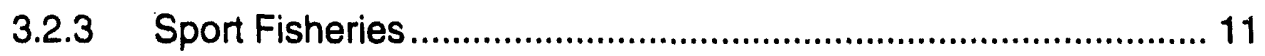

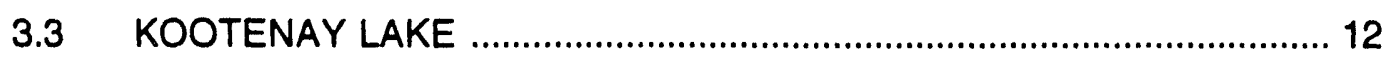

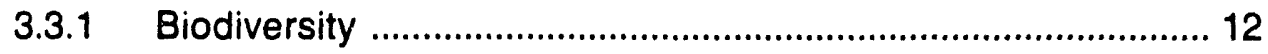

3.3.2 Species-Specific Concerns .................................................... 12

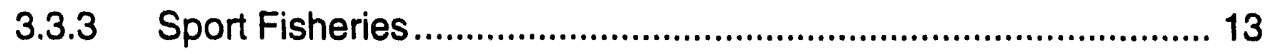

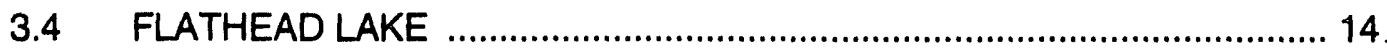

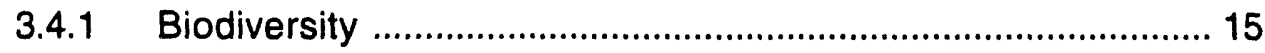

3.4.2 Species-Specific Concerns .................................................. 15

3.4.3 Sport Fisheries...................................................................... 16

3.5 CLARK FORK RIVER BELOW CABINET GORGE DAM..................... 17

3.6 PEND OREILLE RIVER BELOW ALBENI FALLS DAM ...................... 17

3.6.1 Biodiversity ................................................................. 18 
3.6.2 Species-Specific Concerns ....................................................... 18

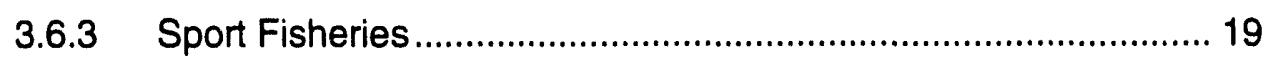

3.7 MID-COLUMBIA RIVER ......................................................................... 20

3.7.1 Biodiversity .......................................................................... 21

3.7.2 Species-Specific Concerns ………………………………...... 21

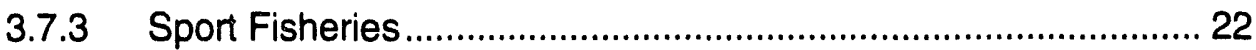

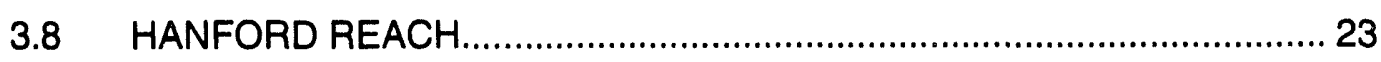

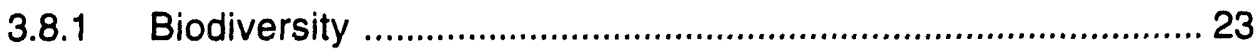

3.8.2 Species-Specific Concerns .................................................... 24

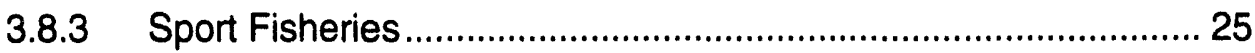

3.9 COLUMBIA RIVER BELOW BONNEVILLE DAM................................... 25

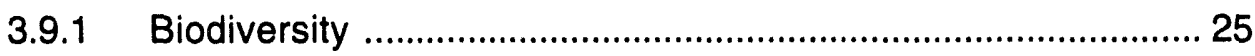

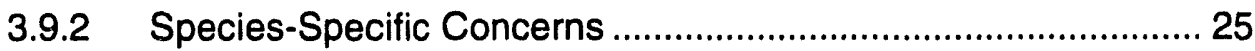

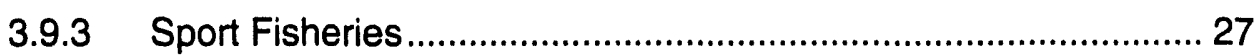

3.10 SNAKE RIVER BELOW HELLS CANYON DAM..................................... 27

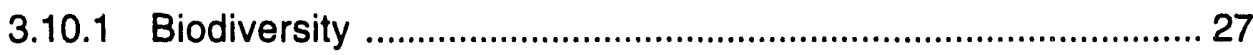

3.10.2 Species-Specific Concerns .................................................. 28

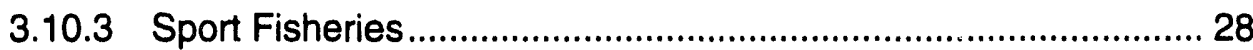

4.0 POTENTIAL IMPACTS TO RESIDENT FISH FROM THE SEVEN PROPOSED SYSTEM OPERATING STRATEGIES ............................... 31

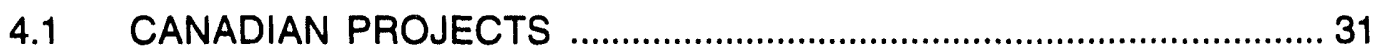

4.1.1 Kinbasket Reservoir, Arrow Lakes, and Kootenay Lake .............. 31

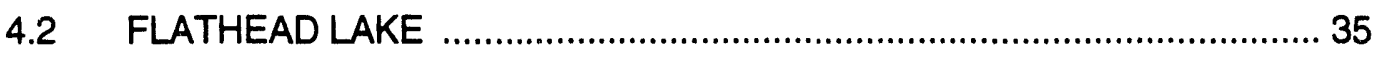

4.3 CLARK FORK RIVER BELOW CABINET GORGE DAM........................ 35

4.4 PEND OREILLE RIVER BELOW ALBENI FALLS DAM ……….............. 35

4.5 LAKE RUFUS WOODS AND COLUMBIA RIVER BELOW

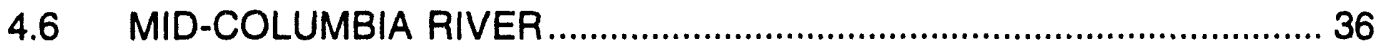

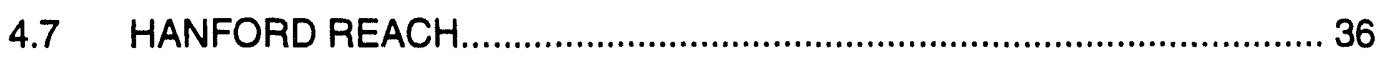


4.8 COLUMBIA RIVER BELOW BONNEVILLE DAM.............................. 37

4.9 SNAKE RIVER BELOW HELLS CANYON DAM................................. 37

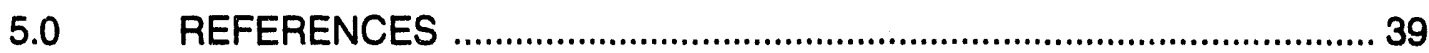




\section{FIGURE}

1.1 The Major Dams of the Snake and Columbia River Drainage Basin .............. 2

\section{TABLES}

2.1 Contacts for Non-Modeled Projects .......................................................... 5

3.1 Morphometric Characteristics of Mainstem Mid-Columbia River

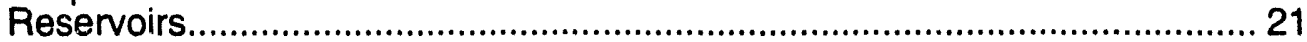

3.2 Resident Fish Species Collected with a 7.9-m Bottom Trawl in the Lower Columbia River Between River Kilometer 46 and 211 from 1988 to 1991.

4.1 Summary of SOS Comparisons for Non-Modeled Projects ........................... 32 


\subsection{INTRODUCTION}

\subsection{BACKGROUND}

The Bonneville Power Administration (BPA), Bureau of Reclamation (BOR), and U.S. Army Corps of Engineers (COE) are currently conducting the System Operation Review (SOR) for the Columbia River basin. The SOR began in 1990 and is expected to provide an operating strategy that will take into consideration multiple uses of the Columbia River system including navigation, flood control, irrigation, power generation, fish migration, fish and wildlife habitat, recreation, water supply, and water quality. The SOR will not only assist agencies in comparing the benefits and risks to Columbia River resources of potential strategies of reservoir operation, but also provide critical data for renegotiating the Canadian Entitlement Allocation Agreements and the Pacific Northwest Coordination Agreement (BPA 1991).

Pacific Northwest Laboratory (PNL)(a) has been assisting BPA and the Resident Fish Work Group (RFWG) in analyzing the impacts to resident fish from all potential alternative forms of system operation. From a list of 91 alternatives for coordinated system operation, the SOR Management Team, has selected 7 alternatives (a total of 21 options) for full-scale analysis. The objective of full-scale analysis is to determine a preferred alternative form of system operation that can be incorporated into an Environmental Impact Statement (EIS). To assist the SOR Management Team with this goal, the RFWG decided to evaluate impacts of the 7 system operation strategies (SOSs) on resident fish at 8 representative reservoir projects: Dworshak Reservoir and the Clearwater River; Albeni Falls Dam/Lake Pend Oreille; Grand Coulee Reservoir; Libby Reservoir and the Kootenai River; Hungry Horse Dam and the Flathead River; the Lower Snake River Reservoirs; John Day Reservoir; and Brownlee Reservoir (RFWG 1993).

Because of concerns about the limited geographic scope of the full-scale analysis, the RFWG expanded the full-scale analysis to include the following additional reservoirs and river reaches: Kinbasket Reservoir, Arrow Lakes, and Kootenay Lake in British Columbia (BC), Canada; Flathead Lake, Montana; Clark Fork River below Cabinet Gorge Dam, Idaho; Pend Oreille River below Albeni Falls Dam, Washington; Lake Rufus Woods and the Columbia River below Chief Joseph Dam, Washington; the Mid-Columbia River below Wells, Rocky Reach, Rock Island, and Wanapum Dams, Washington; the Hanford Reach below Priest Rapids Dam, Washington; the Columbia River below Bonneville Dam, Washington and Oregon; and the Snake River below Hells Canyon Dam, Idaho and Washington (Figure 1.1). These specific locations were identified by regional habitat

(a) Pacific Northwest Laboratory is a multiprogram national laboratory operated for the U.S. Department of Energy by Battelle Mernorial Institute under Contract DE-AC06-76RLO 1830. 


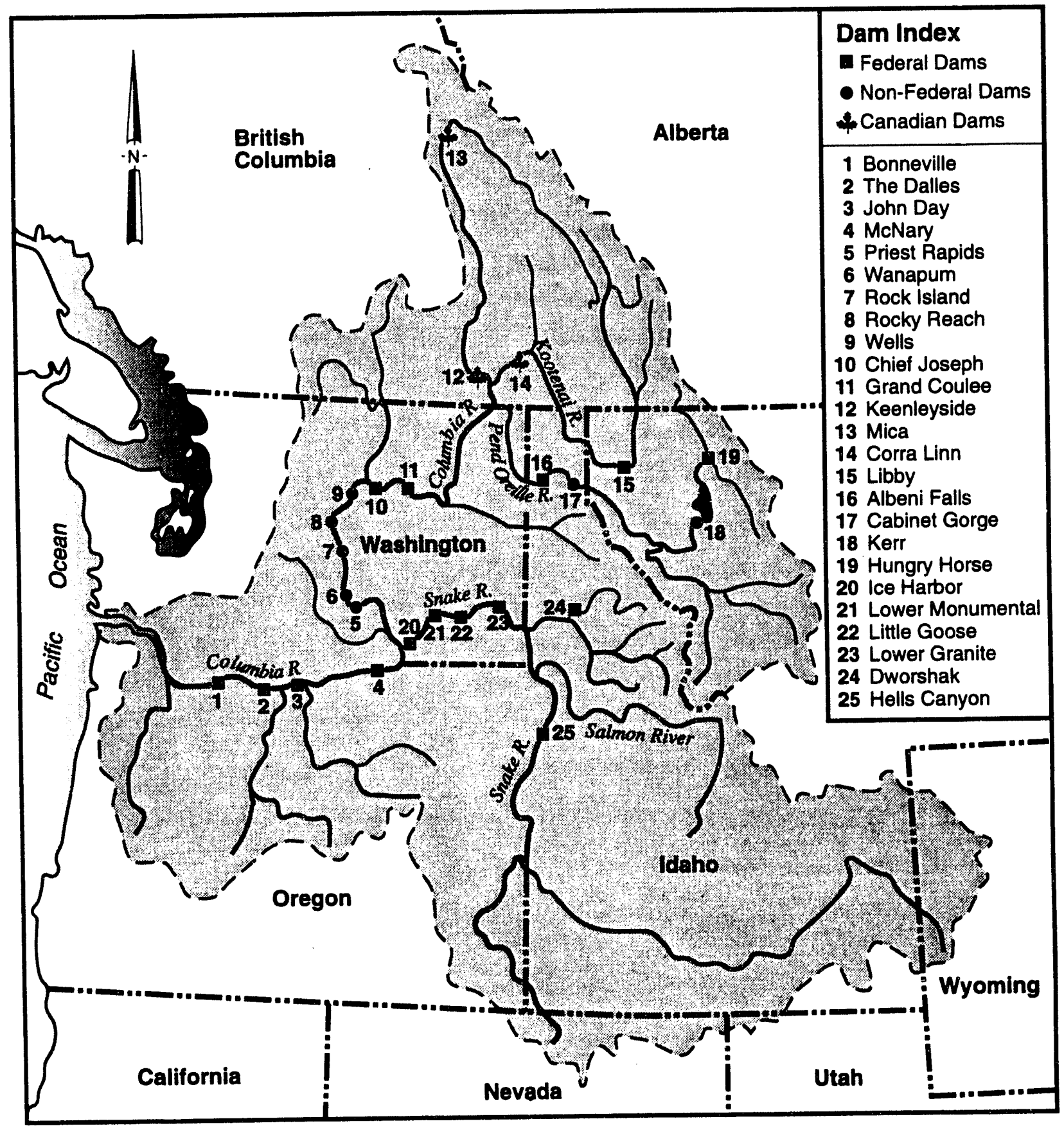

FIGURE 1.1. The Major Dams of the Snake and Columbia River Drainage Basin 
specialists within the RFWG as having resident fish species of either economic or ecological significance. However, quantitative models did not exist for these locations; therefore we initiated a qualitative assessment of potential impacts to resident fish that could result from the $i$ SOSs.

\subsection{OBJECTIVE}

This report provides descriptions of each of the non-modeled reservoirs and other specified river reaches. The descriptions focus on three distinct management goals for resident fish: biodiversity, species-specific concerns, and sport fisheries. In addition, this report provides a qualitative assessment of impacts to the resident fish within these reservoirs and river reaches from the 7 alternative system operating strategies.

In addition to this introduction, the report contains four more sections. Section 2.0 provides the methods that were used. Reservoir descriptions appear in Section 3.0, which is a synthesis of our literature review and interviews with resident fish experts. Section 4.0 contains a discussion of potential impacts to resident fish within each of these reservoirs and river reaches from the 7 proposed system operating strategies. The references cited are listed in Section 5.0. 


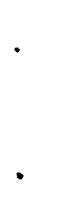




\subsection{METHODS}

Descriptions of the reservoirs were based on a review of the literature and interviews with resident fish experts (identified by RFWG) who were familiar with specific reservoirs (Table 2.1). The interviews focused on three main areas of resident fish management: biodiversity, species-specific concerns, and sport fisheries. Biodiversity was chosen as a management concern to represent all resident fish species that do not fall into a sensitive species category or economically important sport fishery category. The species-specific area of management included such issues as whether the species was petitioned for listing under the Endangered Species Act (ESA); was a state sensitive species; or had some unique characteristic that made it important in a particular location. The sport fishery area of management encompassed those species comprising a healthy sport fishery that generates revenue for the surrounding communities.

Because there were not adequate data to develop detailed quantitative models for each of the reservoirs, a qualitative assessment of the potential impacts to the resident fish at these locations was conducted. This assessment was based on comparisons of the biology and hydrology for each of the non-modeled reservoirs to the projects for which there were existing quantitative models (i.e., Dworshak, Albeni Falls, Grand Coulee, Libby, Hungry Horse, John Day, Lower Granite, and Brownlee reservoirs). If the biology and/or hydrology were not comparable, the assessment of impacts was made strictly by comparing the hydroregulated output (i.e., flows and elevations for each of the SOSs) for that location. An assessment of impacts was not possible if either the biology and hydrology of a non-modeled reservoir were not comparable to a modeled reservoir, or if hydroregulated flow and elevation data were not available for the non-modeled reservoir. 
TABLE 2.1. Contacts for Non-Modeled Projects

Project Name

Kinbasket Reservoir

Arrow Lakes

Kootenay Lake

Flathead Lake

Clark Fork River

Pend Oreille River

Lake Rufus Woods

Mid-Columbia River

Hanford Reach

Columbia River below

Bonneville Dam

Hells Canyon

\section{Contact Person}

Jay Hammond, BC Ministry of Environment Catherine Gee, Canadian Department of Fisheries and Oceans

Jay Hammond, BC Ministry of Environment Catherine Gee, Canadian Department of Fisheries and Oceans

Jay Hammond, BC Ministry of Environment Catherine Gee, Canadian Department of Fisheries and Oceans

Jack Stanford, Flathead Biological Station

Melo Maiolie, Idaho Department of Fish and Game

David Bennett, University of Idaho

Kirk Truscott, Colville Confederated Tribes

Kirk Truscott, Colville Confederated Tribes

Chris Carlson, Grant County Public Utility District

Dennis Dauble, PNL

George McCabe, National Marine Fisheries Service Brad James, Washington Department of Fisheries

Ed Schriever, Idaho Department of Fish and Game Jim Chandler, Idaho Power 


\subsection{RESERVOIR DESCRIPTIONS}

In general, Columbia River dams have modified water flow, temperature regimes, and physical habitat for native resident fish species (BPA 1991). While some native species such as northern squawfish (Ptychocheilus oregonensis) and suckers (Catostomus spp.) appear to have expanded in response to the artificial impoundments, certain endemic fish, in particular westslope cutthroat trout (Oncorhynchus clarki lewisi, formerly Salmo clarki), bull trout (Salvelinus confluentus; formerly known as Dolly Varden in some areas), and white sturgeon (Acipenser transmontanus), have been negatively impacted. Westslope cutthroat trout are designated species of special concern in Montana and are found in both Libby and Hungry Horse resenoirs. On May 17, 1993, the U.S. Fish and Wildlife Service (USFWS) began the one-year status review for listing bull trout as threatened or endangered species under the ESA. In a July 7, 1993, notice in the Federal Register, USFWS proposed listing Kootenai River white sturgeon as endangered, stating that the population is in danger of extinction throughout its range.

In addition, exotic fish species (e.g., walleye [Stizostedion vitreum], smallmouth bass [Micropterus dolomieuI], and largemouth bass [Micropterus salmoides]) have been introduced extensively and often persist in reservoirs in much greater numbers than native fish species, thereby posing a threat to the integrity of these native stocks. Reservoirs are also thought to have dramatically changed the migration, feeding, spawning, and inter- and intra-species behavior of resident fish that evolved under free-flowing river conditions. Yet, despite the magnitude and scope of human-induced alterations of the natural river conditions, resident fish are present in nearly every reservoir within the Columbia River Basin. Resident fish are a valuable resource for sport fisheries, serve cultural and subsistence purposes for native Americans, and contribute to the overall species diversity of the Columbia River Basin (RFWG 1993).

\subsection{KINBASKET RESERVOIR}

Jay Hammond with the BC Ministry of Environment was contacted to request information on resident fish species within Kinbasket Reservoir, Arrow Lakes, and Kootenay Lake. He responded that he could not release any information on Canadian reservoirs unless he was specifically directed to do so by the provincial government. The provincial government did not respond to phone calls or letters requesting their involvement in the SOR process. Subsequently, Catherine Gee of the Canadian Department of Fisheries and Oceans (DFO) began attending RFWG meetings. She attempted to identify sources of information on resident fish populations within these reservoirs but found that few rigorous quantitative studies had been conducted, and very little was known about resident fish at 
these locations. Unless otherwise indicated, the following summaries for Kinbasket Reservoir (Section 3.1), Arrow Lakes (Section 3.2), and Kootenay Lake (Section 3.3) are based on one published report that reviews the impacts of hydroelectric operations on fishery resources in British Columbia (Hirst 1991).

The Kinbasket Reservoir, which resulted from the construction of Mica Dam, includes the natural Kinbasket Lake and McNaughton Reservoir. Owned and operated by B.C. Hydro in accordance with the Columbia River Treaty, Mica Dam generates electricity and provides flood and hydroelectric storage for the lower portions of the Columbia River that lie within the United States. The Kinbasket Reservoir reached full pool for the first time in 1976 and provides a high percentage of the storage capability for the annual runoff within the upper Columbia River watershed. The Kinbasket Reservoir has a maximum surface area of $43,200 \mathrm{ha}$, a maximum volume of $24.7 \times 10^{9} \mathrm{~m}^{3}$, and a mean depth of $57 \mathrm{~m}$. The mean water retention time is 15 months. Spill from the reservoir is relatively uncommon, but annual drawdowns are large (up to $33.4 \mathrm{~m}$ ) because of the large storage capacity of the reservoir. The Columbia River Treaty requirement to use Mica Dam storage to stabilize flows lower down in the Columbia system results in daily and seasonal fluctuations in power production and water availability.

The Kinbasket Reservoir is ultra-oligotrophic (total nitrogen 0.15 to $0.25 \mathrm{mg} / \mathrm{L}$ ). Dissolved oxygen levels are typically at or near saturation (10 to $13 \mathrm{mg} / \mathrm{L}$ ), and $\mathrm{pH}$ varies from 6 to 8 throughout the year. A mild thermocline has been detected by September with $16.6^{\circ} \mathrm{C}$ water at the surface and $9.7^{\circ} \mathrm{C}$ water at $50 \mathrm{~m}$. Cladocerans are the dominant zooplankton, and chlorophyll-a levels are very low (range $<0.5$ to $2.2 \mathrm{mg} / \mathrm{m}^{3}$ ).

\subsubsection{Biodiversity}

The pre-impoundment fish fauna within Kinbasket Lake included bull trout, brook trout ( $S$. fontinalis), rainbow trout (O. mykiss), mountain whitefish (Prosopium williamsoni), and burbot (Lota lota) (R.L. \& L. Environmental Services Ltd. 1992). Following impoundment by Mica Dam, sport fish species reported from Kinbasket Reservoir and tributaries include kokanee (O. nerka, introduced between 1982 and 1985), rainbow trout, bull trout, mountain whitefish, and lake whitefish (Coregonus clupeaformis). Non-sport fish species include longnose sucker (Catostomus catostomus), largescale sucker ( $C$. macrocheilus), bridgelip sucker (C. columbianus), redside shiner (Richardsonius balteatus), peamouth (Mylocheilus caurinus), northern squawtish, longnose dace (Rhinichthys cataractae), prickly sculpin (Cottus asper), and torrent sculpin (C. rhotheus). Based on a hydroacoustic survey in October 1992, kokanee densities in Kinbasket Reservoir were on the order of 100 kokanee/ha as compared to 240 kokanee/ha in Kootenay Lake and 170 kokanee/ha in Lower Arrow Lake (Sebastian and Scholten 1993). 


\subsubsection{Species-Specific Concerns}

Construction of the Mica Dam in 1973 fundamentally changed fish habitat and sportfishing in the upper Columbia River drainage. The dam isolated spawning and rearing habitat for populations of trophy rainbow trout and bull trout from Arrow Lakes that spawned and reared in upper Columbia tributaries. In addition, the Mica Dam flooded lake, river, and stream habitats; reduced or eliminated native fluvial and resident stocks of rainbow trout, bull trout, mountain whitefish, and other sport and non-sport species; and inundated unique river and small lake fisheries (R.L. \& L. Environmental Services Ltd. 1992).

Recognizing that wild fish stocks would no longer meet angler demand, the BC Ministry of Environment concentrated on the establishment of kokanee and trophy rainbow trout (i.e., Gerrard stock) that are better adapted to large lake environments. Between 1982 and 1985 , a total of 549,200 eyed-kokanee eggs and 654,000 kokanee fry were planted in tributary streams. This introduction has been very successful, resulting in kokanee escapements of up to 750,000 fish to the upper Columbia River (R.L. \& L. Environmental Services Ltd. 1992). The success of the Gerrard stock introductions has not yet been determined.

The Mica Dam Fisheries Compensation Program is being developed and implemented through a partnership between B.C. Hydro and the BC Ministry of the Environment (R.L. \& L. Environmental Services Ltd. 1992). This partnership is part of a broad integrated management approach with the following prioritized objectives: 1) to conserve wild fish stocks (sport species will be enhanced for public use and enjoyment, non-sport species will be conserved to maintain biodiversity); 2) to compensate for loss of fish and related recreational opportunities that resulted from the construction of Mica Dam; 3 ) to promote public education and awareness; and 4) to sustain the Fisheries Compensation Program in perpetuity. Under the Program, bull trout are given the highest priority in terms of preserving wild stocks. Priority is also given to kokanee enhancement in order to meet public expectations for enhanced recreational fishing. The emphasis during the initial 5 years of the program is on inventory and assessment of the existing fish stocks and habitats in the program area.

\subsubsection{Sport Fisheries}

Kokanee dominate the sport fish population, with rainbow trout, bull trout, and burbot caught less frequently (Hirst 1991). The gillnet catch-per-unit-effort (CPUE) for sport fish has increased from 6.4 in 1985 to 7.2 in 1987 (R.L. \& L. Environmental Services Ltd. 1992). Many of the streams that are tributary to Kinbasket Reservoir are of glacial origin. These streams are typically steep and cold, exhibit low productivity, and are often ephemeral. Thus, spawning and rearing habitat for sport fish populations is limited. Most of 
the non-glacial streams that provide better spawning habitat are tributary to the mainstem Columbia River above the reservoir. Current levels of recreational angling in Kinbasket Reservoir have not been monitored but are believed to be increasing despite relatively poor access (Hirst 1991).

\subsection{ARROW LAKES}

The Arrow Lakes (Upper and Lower) were impounded in 1967 with the completion of Keenleyside Dam, a Columbia River Treaty project designed to provide hydroelectric storage and flood control for the benefit of downstream projects within the United States. The concrete dam at the lower end of Lower Arrow Lake is $58 \mathrm{~m}$ high and $869 \mathrm{~m}$ long, and it is not equipped with hydroelectric turbines. The water level in the Arrow Lakes reached the maximum operating level for the first time by mid-1969.

Keenleyside Dam has no fishway. Protracted negotiations between B.C. Hydro and the BC Ministry of Environment over a 20-year period following project completion led to the provision of $\$ 3$ million (Canadian funds) in 1986 to the BC Ministry of Environment for fisheries compensation. In 1986, a proposed fish ladder at Inonoaklin Falls was abandoned as a fisheries compensation measure because of agricultural water-use conflicts. Instead, the production capacity of the Hill Creek hatchery (built as compensation for impacts resulting from the construction of Revelstoke Dam) was doubled.

The Arrow Lakes were operated to capture as much of the annual spring flood as possible within the constraints of a maximum reservoir operating level of $440.7 \mathrm{~m}$. Annual evacuation of the reservoir for downstream uses is $60 \%$ to $85 \%$, with correspondingly large drawdowns, typically reaching 15 to $20 \mathrm{~m}$ below full pool. In an effort to minimize dissolved gas concentrations, water is normally passed through the low-level ports only when the hydraulic head is less than $10 \mathrm{~m}$, and the associated flows are less than $1400 \mathrm{~m} / \mathrm{s}$. B.C. Hydro is presently investigating the exact limitations of low-level port use as a means to reduce total gas pressure downstream.

The Arrow Lakes are steep-sided and narrow, with rocky shorelines and narrow gravel beaches. The post-impoundment mean depth is approximately $18 \mathrm{~m}$. The lakes are oligotrophic with total phosphorus levels ranging from 0.005 to $0.019 \mathrm{mg} / \mathrm{L}$ and total nitrogen levels ranging from 0.15 to $0.24 \mathrm{mg} / \mathrm{L}$. There is no indication of nutrient loading from bottom sediments. The lakes are slightly alkaline and do not normally become significantly thermally stratified. Metals and chlorophyll-a content are low. Primary production in the lake is dominated by several species of diatoms. Copepods are the dominant component of a diverse zooplankton population. Chironomids (midges) dominate the benthos. 


\subsubsection{Biodiversity}

A list of probable sport fish species found in the lakes prior to impoundment included mountain and lake whitefish, eastern brook trout, Yellowstone cutthroat trout (O. clarki), rainbow trout, bull trout, kokanee, burbot, and white sturgeon. Other non-sport fish species were pygmy whitefish ( $P$. coulteri), largescale sucker, longnose sucker, bridgelip sucker, northern squawfish, redside shiner, carp (Cyprinus carpio), peamouth, lake chub (Couesius plumbeus), leopard dace ( $R$. falcatus), longnose dace, prickly sculpin, torrent sculpin, and slimy sculpin (C. cognatus) (Ash et al. 1982).

Data on fish species present in the lakes post-impoundment are very limited. Kokanee comprised about one-half of all fish sampled in the northern end of Upper Arrow Lake in the summer of 1990 , while bull trout represented roughly one-quarter of total gill net catches. Rainbow trout and mountain whitefish each made up small proportions of samples.

\subsubsection{Species-Specific Concerns}

No species-specific concerns were identified.

\subsubsection{Sport Fisheries}

Rainbow trout, bull trout, and kokanee are the primary sport fisheries in Arrow Lakes. Kokanee are fished throughout the summer. Bull trout are fished in the fall and winter. Rainbow trout are sought in spring and summer. Angling effort for rainbow trout and bull trout in both Lower and Upper Arrow Lakes has decreased in the decade since completion of Keenleyside Dam. In contrast, angler effort and returns for kokanee have markedly increased in Upper Arrow Lake since construction of Revelstoke Dam because of the construction of the Hill Creek hatchery and the Hill-Mackenzie Creek spawning channel in 1980 (built as compensation for Revelstoke impacts). By 1986, the angling success rate for kokanee reached about 1.5 fish per angling hour. The high production of kokanee has resulted in a decrease in size, and thus the species' value as a sport fish is likely to decline. Significant numbers of hatchery-bred rainbow trout and bull trout were beginning to appear in sport fish catches in Upper Arrow Lake by 1986.

The Arrow Lakes are unique in terms of angling in large British Columbia lakes in that bull trout are actively sought by anglers. Despite the steady decreases in rainbow and bull trout catches, the Arrow Lakes provide lake fishing comparable to that obtained in Kootenay Lake. The numbers and success ratios per angler are higher in Arrow Lakes than Kootenay Lake, but the fish are smaller. 


\subsection{KOOTENAY LAKE}

Kootenay Lake is a natural lake occupying the central portion of the Purcell Trench. It has a surface area of $38,900 \mathrm{ha}$ and a mean depth of $94 \mathrm{~m}$, and it receives the flow from three major rivers--Kootenay, Duncan, and Lardeau. Approximately $57 \%$ of the lake inflow is currently regulated for hydroelectric and flood control purposes. Flow regulations commenced with Corra Linn Dam on the Kootenay River in 1932 (power generation), Duncan Dam on the Duncan River in 1967 (flood control and Columbia River treaty storage), and Libby Dam on the Kootenai River in 1973 (Columbia River treaty storage and power generation). Because of its large volume, Kootenay Lake annual storage amounts to over $1.4 \times 10^{9} \mathrm{~m}^{3}$. Lake levels are primarily a function of two factors: water releases from Duncan and Libby reservoirs and unregulated run-off from numerous smaller tributaries. The mean water retention time of the entire lake is estimated at 15.9 months. However, the west arm has a mean retention time of only 5 days because of its narrow configuration and direct connection to the lake outtlow.

The lake is thermally stratified from mid-June through the end of October. Summer water temperatures at the surface reach 16 to $18^{\circ} \mathrm{C}$ and the $10^{\circ} \mathrm{C}$ isotherm typically extends down to a depth of 20 to $30 \mathrm{~m}$. Prior to 1950, Kootenay Lake was oligotrophic, typical of most large lakes in British Columbia. In the early 1950s, in response to increased phosphorous and nitrogen loadings resulting from the effluent discharged from a fertilizer plant, phytoplankton and zooplankton concentrations increased to such an extent that algal blooms were common in the 1960s. Following eutrophication in the early 1950 s through the mid 1960 s, a period of nutrient decline was initiated by pollution abatement measures at the fertilizer plant in 1969 and exacerbated by nutrient retention behind Libby and Duncan dams. In an attempt to improve the productivity of some sections of the lake, phosphate enrichment commenced in the west arm on a pilot basis in 1986 and in the north arm in 1992.

\subsubsection{Biodiversity}

Predam descriptions of resident fish species within Kootenay Lake could not be located. However, kokanee have been harvested by sportishers since the $1930 \mathrm{~s}$. Kootenay Lake is currently known to support populations of rainbow trout, bull trout, kokanee, mountain whitefish, and burbot. No data are available on other resident fish species that do not support sport fisheries.

\subsubsection{Species-Specific Concerns}

Kokanee are the most abundant sport fish within Kootenay Lake and consist of three racially distinct populations--north arm, south arm, and west arm stocks. In response to nutrient enrichment of the lake in the 1950s and 1960s, the west arm kokanee population increased in size, attracting many anglers. High angling catches and success rates followed 
the rise in eutrophication up until the 1970 s when the kokanee population crashed. There is strong evidence that the kokanee collapse was a product of dam construction/operation on the main tributaries to Kootenay Lake and the introduction of mysid shrimp (Mysis relicta), which are an efficient competitor with kokanee for zooplankton (Ashley and Thompson 1993). The kokanee fishery has been closed since 1980 in an effort to restore kokanee populations. Kokanee stocks have not responded to production at two west arm spawning channels.

The kokanee population crash directly impacts the Gerrard rainbow trout population, which depends upon kokanee as their main food source, and therefore is of considerable concern to the BC Ministry of Environment (Fish and Wildlife Branch), to anglers, and to local communities that rely on tourism/fishing (Catherine Gee, Fisheries and Oceans, personal communication 1993). A recent report (Korman et al. 1990) examined the technical, economic, and practical aspects of fertilization of the north arm of Kootenay Lake for enhancement of kokanee, Gerrard rainbow trout, and bull trout. The results of this study suggested that a doubling in fish production could be achieved if total phosphorus and maximum phytoplankton concentrations were increased to levels of two to three times present levels. The predicted economic gains resulting from lake fertilization were a doubling of the present value of resident fish species from slightly under $\$ 600,000$ annually to a value of $\$ 1,200,000$ annually (Canadian funds). The conclusion of the study was that the projected long-term economic gains of the project were well above the associated implementation and monitoring costs.

In early 1992, the decision was made to proceed with an experimental fertilization of Kootenay Lake conducted within an adaptive environmental assessment. A total of 864 metric tonnes (MT) of fertilizer was applied in a 10-km section of the north arm. The seasonal loading and timing of fertilizer application was designed to simulate preimpoundment phosphorus and nitrogen loading. Preliminary results reported by Ashley and Thompson (1993) are inconclusive regarding the effect of fertilization on kokanee salmon. The mobility of kokanee precluded correlation of fish size to the nutrient gradient. Spawners in 1992 were larger than in any year since 1969, and fecundities (300 eggs/female) were the third highest observed during this period. Ongoing studies that will provide additional insight into the effects of the fertilization program include a surface transport study (dye tracing and acoustic doppler current profiling); resonant enhanced mysid export study; west arm mysid export study; biweekly physical, chemical, and plankton sampling; ecosystem dynamics study; and kokanee and mysid acoustic sampling.

\subsubsection{Sport Fisheries}

Sportfishing has been a major recreational pursuit on Kootenay Lake since at least the 1930s. Sportfishing in the Kootenay region was estimated to have a total value of 
about $\$ 18$ million in 1981, of which the Kootenay Lake fishery provided a large proportion. Trophy rainbow trout have been the primary attraction. The rainbow trout population in the lake consists of distinct stocks. The Gerard stock matures later than other stocks and attains weights of 8 to $20 \mathrm{~kg}$, making them the main trophy angling species in the lake. The trout population in the main lake consists of Gerrard stocks, while the south and west arms support smaller trout that seldom exceed $5 \mathrm{~kg}$ in size.

Bull trout, which are also actively sought by anglers on Kootenay Lake, can grow to $15 \mathrm{~kg}$ in size. To date, management efforts on bull trout have been relatively limited, consisting mainly of stocking major tributaries. Trends in bull trout catches and effort are not well defined because of high inter-annual variability, although catches and effort have increased in the south arm in recent years.

Historically, more than $50 \%$ of the angling activity on the lake was directed toward kokanee stocks, prior to the fishery being closed in 1980. Mountain whitefish are abundant in the lake but are mainly incidental species in angling catches. In the 1950s and 1960s they were taken in large numbers, but angling effort and catches have markedly declined because of an overall decline in angling interest in conjunction with the depressed economic conditions in the region.

Burbot are actively fished in the west arm by a small number of anglers. Catches are thought to have declined since the construction of Libby Dam and the reduction in peak flows through the west arm.

\subsection{FLATHEAD LAKE}

Flathead Lake is the largest natural lake in the western United States, with a maximum length of $43.9 \mathrm{~km}$ and a surface area of $50,990 \mathrm{ha}$. It has a maximum depth of 113 $\mathrm{m}$ and a mean depth of $32.5 \mathrm{~m}$ (Fraley et al. 1989). The Flathead River is the largest tributary to the lake with an average annual flow of $340 \mathrm{~m}^{3} / \mathrm{sec}$. Seventy-two percent of the Flathead River catchment $\left(22,241 \mathrm{~km}^{2}\right)$ is federally designated and protected as wilderness or national park (Stanford and Hauer 1992).

Operated by Montana Power Company, Kerr Dam was completed in 1938 and controls the flow from Flathead Lake. The dam is located $6.4 \mathrm{~km}$ downstream of the lake's natural outlet. Operation of the dam normally results in annual lake level fluctuations of about $3 \mathrm{~m}$. During the summer recreation season, the lake is maintained at the highest level possible. Drawdown for flood control and power generation typically begins in midSeptember, with minimum pool reached by April 15.

The lake is oligo-mesotrophic in terms of algal productivity, water clarity, dominant phytoplankton species, and total dissolved solids, with accelerated eutrophication occurring 
in recent years (Cross and Waite 1988). Compared to most other lakes in the United States, Flathead Lake has low nitrogen and phosphorus concentrations and does not produce much plant and animal material naturally (Stanford and Hauer 1992). Because the flood waters are the most important source of nutrients for the lake, annual algal production is controlled by the duration and volume of the spring run-off (Stanford et al. 1983; Stanford and Ellis 1988). In the past decade, fertilization of the lake from human sources (sewage, air pollution from wood burning, agricultural and forest run-off) has been a major concern. An estimated $17 \%$ of the annual phosphate input into the system is from sewage (Stanford and Hauer 1992).

The Flathead River-Lake ecosystem is one of the most thoroughly documented stream regulation case histories in the world (Jack Stanford, personal communication, August 1992). Stanford and Hauer (1992) reviewed more than 50 scientific papers and management reports that included data and interpretations of ecological effects of water regulation in the Flathead River-Lake ecosystem. They concluded that "the fundamental problem with the regulation of stream flows and lake levels in the Flathead River catchment is that Kerr and Hungry Horse dams are operated independently, when in faci they are interrelated economically and ecologically." Correcting ecological problems caused by the operation of these dams will require a holistic, ecosystem perspective. Stanford and Hauer (1992) recommended that the most pervasive influences of stream and lake regulation can be improved by 1) retrofitting the cold-water release dam with a selective depth outlet structure to allow temperature control and 2) controlling changes in flow rates (i.e., eliminating peaking operations) to create a more natural hydrograph in the tailwaters of the large dams.

\subsubsection{Biodiversity}

More than 20 fish species coexist in Flathead Lake, owing to intense competition for scarce food supplies and limited habitats. The lake is a "melting pot" of biodiversity and includes many species on the fringe of their continental distribution (Stanford and Hauer 1992). The most successful exotic species were introduced in the 1930s, and the species assemblage of the lake changed very little up until the recent introduction of the opposum shrimp (Mysis relicta), which is thought to have grossly restructured the lake's food webs (Spencer et al. 1991).

\subsubsection{Species-Specific Concerns}

The Flathead Lake system currently supports only nine native species. Three dams (Bigfork, Kerr, and Hungry Horse dams), which were built for hydropower production and flood control, blocked over half of the former range of native migratory fish from Flathead Lake (Stanford and Hauer 1992). These native species, although highly adapted to the dynamics of the natural environment, are very sensitive to human-induced changes. The principal native species of special concern are bull trout (Fraley and Shepard 1989) and 
westslope cutthroat trout (Marnell et al. 1987). Both species are relatively rare in North America, largely because humans have eliminated them from less pristine areas. Fraley et al. (1989) estimated annual losses from the Flathead Lake ecosystem of 65,500 migratory juvenile, westslope cutthroat trout and 1,965 adult migratory bull trout as a result of the construction of Hungry Horse Dam. Reproductive isolation, restricted access to spawning grounds, excessive harvest, and the introduction of non-native species have all contributed to the marked decline of bull trout and westslope cutthroat trout (Stanford and Hauer 1992).

\subsubsection{Sport Fisheries}

Historically, the principal sport fishery in Flathead Lake was for kokanee salmon, which until the early 1980 s supported a summer troll fishery, a fall snag fishery during the spawning run, and a winter troll or ice fishery. Kokanee salmon have been the subject of considerable study, and it is well documented that they were very abundant in Flathead Lake prior to the construction of Kerr Dam (Stanford and Hauer 1992). Because kokanee salmon spawn on the shoreline of Flathead Lake, they are particularly vulnerable to lake level fluctuations. Studies of the effects of hydroelectric operations on the reproductive success of kokanee in the Flathead Lake ecosystem have been ongoing since 1980. The results of these studies have been published in a series of annual progress reports that were reviewed by Beattie et al. (1988). Spencer et al. (1991) concluded that the collapse of the kokanee fishery can be attributed to a variety of factors including stream and lakelevel regulation, altered flow and temperature regimes, decreased kokanee stocking rates, alteration of shoreline spawning habitats by erosion, changes in groundwater flow patterns as a result of shoreline development, overfishing, and the establishment of the opposum shrimp, which virtually eliminated the zooplankton food supply for kokanee. The combined operation of Hungry Horse and Kerr dams causes annual losses conservatively estimated at 96,300 river-spawning and 131,000 lakeshore-spawning kokanee adults (Fraley et al. 1989).

Fraley et al. (1989) recommended changes to Kerr Dam operations to provide significant benefit for kokanee reproduction on the Flathead Lake shoreline. In addition, they proposed supplementing recruitment in the lake by planting hatchery-reared kokanee fry. However, Stanford and Hauer (1992) contend that augmentation of the damaged kokanee fishery with hatchery stocks may be costly and ineffective if water quality and other habitat problems associated with dam operations, such as temperature and flow volume, are not solved first. In addition, cascading food web interactions elicited by invasions of non-native biota such as the opposum shrimp may offset any advantage conferred by augmentation. Beattie et al. (1988) concluded that if the kokanee fishery is not viable over the long term, the emphasis for management will shift to other species such as lake trout, bull trout, and westslope cutthroat trout. 
Since the introduction of opossum shrimp, which essentially extirpated the primary planktivorous fishery, lake whitefish and yellow perch (Perca flavescens) have dominated the lake system (Stanford and Hauer 1992). These two species combined account for $45 \%$ to $89 \%$ of the total fish abundance in the lake. The growing importance of the perch fishery is illustrated by creel survey comparisons conducted by Cross and Waite (1988). In 1966, yellow perch harvest comprised $17 \%$ of the total lake-wide catch. By 1982 , the percentage of perch in angler's creels increased to $33 \%$, and anglers harvested between 30,000 and 40,000 perch annually from the South Bay of Flathead Lake alone.

Other important sport fish include lake trout (Salvelinus namaycush), largemouth bass, northern squawtish, and mountain whitefish. Cross and Waite (1988) presented evidence that yellow perch probably control recruitment of largemouth bass by preying directly upon young bass and/or competing with them for a limited food supply. Additional evidence suggests that the pattern of hydroelectric operations may actually benefit yellow perch by reducing recruitment, preventing stunting, and providing a ready forage base in winter when aquatic insects may not be readily available.

\subsection{CLARK FORK RIVER BELOW CABINET GORGE DAM}

The Clark Fork River has a drainage area of $56,980 \mathrm{~km}^{2}$, with a mean annual discharge of $585 \mathrm{~m}^{3} / \mathrm{s}\left(2,832 \mathrm{~m} 3 / \mathrm{s} \mathrm{max}\right.$., $<85 \mathrm{~m}^{3} / \mathrm{s} \mathrm{min}$.). Blocking of upstream spawning migrations by Cabinet Gorge Dam began during the construction period of 1951; fluctuation of flows below the dam began in the fall of 1952. The kokanee spawning run in the Clark Fork River was essentially eliminated when Cabinet Gorge Dam was constructed.

Peaking power operations at Cabinet Gorge are the limiting factor for resident fish species within the Clark Fork River (Melo Maiolie personal communication, September 1992). Fish stocks have probably been depressed by extreme daily fluctuations in instream flow, which range from $425 \mathrm{~m}^{3} / \mathrm{s}$ to $85 \mathrm{~m}^{3} / \mathrm{s}$ (Maiolie et al. 1991). Currently, there is no mandated instream flow.

Melo Maiolie recommended that, unless models exist for peaking flows, the Clark Fork River should not be included in the full-scale analysis (personal communication, September 1992).

\subsection{PEND OREILLE RIVER BELOW ALBENI FALLS DAM}

This discussion is limited to resident fish populations within the Box Canyon portion of the Pend Oreille River. The sections that follow are based on a 2-year fishery survey conducted by Bennett and Liter (1991) and a 3-year assessment of fishery improvement opportunities on the Box Canyon portion of the Pend Oreille River conducted by Ashe et al. (1991). 
The Box Canyon reservoir extends $89.8 \mathrm{~km}$ from Albeni Falls Dam downstream to Box Canyon Dam. Total surface area of the reservoir is 2,983 ha with a mean depth between 2.7 and $12.2 \mathrm{~m}$. The upstream drainage area consists of $62,678 \mathrm{~km}^{2}$ of forested mountains and large, wide, mid-elevation valleys. Based on monthly flows at Newport, Washington, the normal high flow month is June with a mean discharge of $12,886 \mathrm{~m} 3 / \mathrm{s}$. The normal low flow month is August with a mean discharge of $337 \mathrm{~m} 3 / \mathrm{s}$.

Prior to completion of Box Canyon Dam, the Pend Oreille River was primarily a coldwater fishery. Rainbow trout, cutthroat trout, and mountain whitefish r.aade up most of the fish caught. However, dam construction resulted in the river changing from a free-flowing system to a run-of-the-river reservoir, thereby creating more favorable habitat for warmwater species. In particular, inundation resulted in the formation of shallow sloughs that provided spawning areas for yellow perch, tench (Tinca tinca), and suckers. Inundation also created more favorable habitat for native and exotic species of aquatic vegetation (e.g., Eurasian milfoil). This dense vegetation provided yellow perch, tench, and suckers with spawning habitat, food, and protection from predation. The habitat changes resulting from dam construction and inundation caused a dramatic faunal shift from coldwater to warmwater species. Largemouth bass, walleye, and other non-native, warmwater species were subsequently introduced.

\subsubsection{Biodiversity}

Bennett and Liter (1991) collected a total of 29,213 fish representing 21 species during th:air 1989 to 1990 survey. Yellow perch, pumpkinseed (Lepomis gibbossus), and largemouth bass were the game species highest in relative abundance, while northern squawfish, tench, and largescale sucker were the more abundant non-game species. Brown trout (Salmo trutta), cutthroat trout, and rainbow trout were also captured, although none of these species were higher than $1 \%$ in relative abundance. Electrofishing surveys conducted by Ashe et al. (1991) from February through October 1990 resulted in a total catch of 9,933 fish representing 20 species. The catch was composed of $44.8 \%$ yellow perch, $10.5 \%$ tench, $10.3 \%$ pumpkinseed, $8.5 \%$ largemouth bass, $7.1 \%$ mountain whitefish, $5.9 \%$ largescale sucker, and $3.6 \%$ longnose dace. Trout were uncommon, representing only $1 \%$ of the total catch. Overall, non-game species dominated the reservoir by biomass and numerically. Collectively, suckers, tench, northern squawfish, small yellow perch, and pumpkinseed comprised $83 \%$ (by number) of the fishes in the reservoir.

\subsubsection{Species-Specific Concerns}

Although native cutthroat and bull trout are the principal species of concern, the habitat of the Pend Oreille River appears to be unsuitable for trout production. Tributaries to the Box Canyon Reservoir are low-order, high-gradient streams, which are typically 
unproductive. Ashe et al. (1991) suggested that one way to enhance the production of native trout species would be to discontinue stocking brook trout and actively remove the existing stocks that directly compete with the native species. Alternatively, Bennett and Liter (1991) advocated creating runs of trout that would migrate from the tributaries to the reservoir. Both studies (Bennett and Liter 1991; Ashe et al. 1991) concluded that efforts aimed at habitat improvement or fish population enhancement would best be directed toward largemouth bass. Recruitment was identified as being the major limiting factor for largemouth bass (Bennett and Liter 1991). Water temperatures that control growth and the timing of spawning, water level fluctuations, and organized fishing tournaments all impact bass recruitment.

Bennett and Liter (1991) also noted that any successful fisheries restoration program must be long-term in scope and effectively utilize the existing aquatic vegetation as an important habitat attribute, because it is unlikely that the vegetation will ever be effectively eliminated.

\subsubsection{Sport Fisheries}

Although yellow perch are the most abundant species in the reservoir, their small average size $(15 \mathrm{~cm})$ is unacceptable to sport anglers. The predominant sport fish species in the reservoir is largemouth bass, the only sport species with a large enough population of individuals of sufficient size to attract anglers. The bass fishery is increasing in popularity and several bass tournaments are held on the river each year. Most of the bass anglers practice catch-and-release fishing. In 1988, the estimated sport harvest of largemouth bass was $389 \pm 40$ and in 1989 the estimated harvest was $103 \pm 12$ (Ashe et al. 1991).

From March through Decenber 1988, angler effort for all sport fish was estimated at $4,139 \pm 467$ hours. In 1989, effort decreased to 3,029 \pm 374 hours. An estimated 2,505 \pm 312 fish were harvested in 1988, compared to 1,331 \pm 164 in 1989 (Ashe et al. 1991).

Optimal riverine habitat for largemouth bass is characterized by large, slow-moving rivers with soft bottoms, aquatic vegetation, and relatively clear water (Stuber et al. 1982). Although the Pend Oreille River appears to have optimal habitat for bass production, low water temperatures and water level fluctuations of the reservoir may limit reproduction, recruitment, and growth (Bennett and Liter 1991). During the first 4 years of their life cycle, growth rates for largemouth bass in the Box Canyon Reservoir were lower than growth rates for bass from other locations in the northwestern United States, but rates were comparable or higher to those at other locations after age 4. Dramatic natural fluctuations in flow probably result in the observed fluctuations in year class strength (Bennett and Liter 1991). 
Ashe et al. (1991) recommended enhancing the largemouth bass population by building a small facility to hatch largemouth bass and wetland rearing ponds to raise the fish to a size near $20 \mathrm{~cm}$. At that size, bass become piscivorous, and they could be released into the reservoir. Such an enhancement program might diminish the problems of densitydependent mortality and depletion of the food supply. Bennett and Liter (1991) suggested stocking 1-year-old largemouth bass to enhance recruitment during periods of weak age-1 year classes.

\subsection{MID-COLUMBIA RIVER}

Based on conversations with Kirk Truscott of the Confederated Colville Tribes (personal communication, August 1992), there are few published studies documenting resident fish utilization of the Columbia River below Chief Joseph Dam. Chris Carlson, a fisheries biologist with Grant County Public Utility District (PUD), knew of only one resident fish study that has been conducted in Wells, Rocky Reach, Wanapum, and Rock Island reservoirs (personal communication, September 1992). That study (Mullan et al. 1986) was conducted jointly by U.S. Fish and Wildife Service (USFWS), Grant County PUD, Chelan County PUD, and Douglas County PUD.

For the purposes of this report, the mid-Columbia River is defined as the area between Chief Joseph Dam and Priest Rapids Dam, which includes the reservoirs created by the Wells, Rocky Reach, Wanapum, and Priest Rapids hydroelectric dams (see Table 3.1). Typically, the Hanford Reach below Priest Rapids Dam is also considered the midColumbia. In this report, however, the Hanford Reach is discussed in a separate section because it is unique relative to the other mid-Columbia reservoirs. The Hanford Reach is the last free-flowing, yet regulated, stretch of the Columbia River remaining above Bonneville Dam.

The mid-Columbia reservoirs function primarily as coldwater tailwaters to the Grand Coulee Dam storage reservoir, Lake Roosevelt, which is the only mainstem storage reservoir in the U.S. portion of the river. The small volumes and high flushing rates (1 to 6 days) of reservoirs in the mid-Columbia River place them in a run-of-river category with smaller fluctuations in stage occurring weekly, rather than seasonally (Mullan et al. 1986). Constraints imposed on endemic species by reduction in spring-summer water temperatures are not well understood, but it is reasonably well documented that exotic warmwater species spawn successfully only in atypical warm backwaters. Introductions of exotic species and hydroelectric development have radically altered the abundance of many indigenous species in the Columbia River. Indigenous salmonids, Pacific lamprey (Entosphenus tridentatus), and sturgeon are almost non-existent in mid-Columbia 
TABLE 3.1. Morphometric Characteristics of Mainstem Mid-Columbia River Reservoirs

\begin{tabular}{|c|c|c|c|c|c|c|}
\hline \multirow{2}{*}{$\begin{array}{l}\text { River } \\
(\mathrm{km})\end{array}$} & \multirow[b]{2}{*}{ Reservoir } & \multicolumn{2}{|c|}{ Distance (km) } & \multicolumn{2}{|c|}{ Surface Area (ha) } & \multirow{2}{*}{$\begin{array}{l}\text { Average } \\
\text { Depth (m) }\end{array}$} \\
\hline & & Length & Shoreline & Reservoir & Original River & \\
\hline $\begin{array}{l}639 \\
668 \\
729 \\
763 \\
830\end{array}$ & $\begin{array}{l}\text { Priest Rapids } \\
\text { Wanapum } \\
\text { Rock Island } \\
\text { Rocky Reach } \\
\text { Wells }\end{array}$ & $\begin{array}{l}29.0 \\
61.1 \\
33.8 \\
67.6 \\
47.0\end{array}$ & $\begin{array}{r}92.5 \\
151.2 \\
69.2 \\
149.6 \\
160.0\end{array}$ & $\begin{array}{l}3,367 \\
5,957 \\
1,404 \\
3,966 \\
3,864\end{array}$ & $\begin{array}{l}1,746 \\
2,813 \\
1,125 \\
1,906 \\
1,684\end{array}$ & $\begin{array}{r}7.3 \\
14.9 \\
10.1 \\
13.4 \\
9.4\end{array}$ \\
\hline
\end{tabular}

reservoirs, and the fish community is now dominated by sticklebacks (Gasterosteus aculeatus), cyprinids, and suckers (Mullan et al. 1986) .

\subsubsection{Biodiversity}

Mullan et al. (1986) reported 24 resident fish species that were counted as they ascended fishways at mid-Columbia dams. It was not clear whether ascending resident fishes represented a spawning migration, random movement, or a response to environmental factors.

Dell et al. (1975) collected 27 species of resident and anadromous fish in their study on gas bubble disease symptoms of fish in the mid-Columbia river reservoirs. Game fish numbered 3,016 and included juvenile salmonids, rainbow trout, bull trout, walleye, largemouth bass, smallmouth bass, yellow perch, black crappie (Pomoxis nigromaculatus), sunfish (Lepomis spp.), black bullheads (Ictalurus melas), brown bullheads (I. nebulosus), and mountain whitefish. Non-game resident fish numbered 29,273 and included carp, suckers, northern squawfish, peamouth, redside shiners, sculpins, dace, sticklebacks, tench, and Pacific lamprey (Entosphenus tridentatus). The total fish catch by reservoir was Wells 4,231; Rocky Reach 8,139; Rock Island 2,245; Wanapum 17,301; and Priest Rapids 373.

Rogers et al. (1989) conducted monthly electroshocking surveys in the Priest Rapids pool from May to August 1988. The principal species they collected was largescale sucker; other common species were redside shiner, northern squawtish, chiselmouth, mountain whitefish, and carp.

\subsubsection{Species-Specific Concerns}

Pacific lamprey have been severely reduced by the impoundment of the Columbia River. The demise of Pacific lamprey in the mid-Columbia River brackets a life cycle of 7 to 9 years (Mullan et al. 1986). The last remaining site for lamprey spawning in the mid-Columbia River was eradicated by the Wells Dam impoundment in 1967. Counts of 
lamprey at Rocky Reach Dam declined from 17,200 in 1969 to less than 200 by 1976 . For the years 1973 to 1982 , counts at Rock Island Dam reflected the same declining trend.

Despite appreciable tributary spawning areas (e.g., Wenatchee, Entiat, and Methow rivers), trout are uncommon in mid-Columbia reservoirs (Mullan et al. 1986). How trout production might be increased in reservoirs above Priest Rapids Dam is unclear.

\subsubsection{Sport Fisheries}

The two principal sport fish species throughout the mid-Columbia River are walleye and smallmouth bass (Bennett 1991). Little information is available on the absolute or current relative abundance of these two species in the mid-Columbia reservoirs.

Although historically they were taken only as incidental catch, northern squawfish are increasingly targeted by anglers because of the bounty placed on this species. Walleye are voracious predators and are considered a threat to salmon smolts that migrate through the reservoirs, as well as resident fish species. The northern squawfish is a slowgrowing, long-lived, and late-maturing species. According to Bennett (1991), published and unpublished data suggest a relatively high abundance of northern squawfish in the midColumbia reservoirs. One factor that may limit squawfish abundance in the mid-Columbia reservoirs is shallow-water rearing habitat for young-of-year $(<5 \mathrm{~cm})$. Walleye fisheries peaked in the Wells and Rocky Reach systems from 1979 to 1980 and then declined abruptly in 1981 (Bennett 1991). Presently, a small walleye fishery exists during the spring in the Chelan River and at the tailrace of the Wells Dam when the walleye are concentrated for spawning. Walleye are apparently recruited to the mid-Columbia River from Lake Roosevelt, where they were introduced in the 1950s. In Lake Roosevelt, walleye are the dominant sport fish, and they are subject to an annual exploitation of $35 \%$ of the fish over $30.5 \mathrm{~cm}$. Annual sport catches of walleye amount to a little over $1 \mathrm{~kg} / \mathrm{ha}$. Sporadic sport catches of exceptionally fast growing 2.3- to 7.3-kg walleye in the mid-Columbia reservoirs suggest low overall densities (Mullan et al. 1986). The authors suggest that walleye populations could possibly be increased by stocking large-size juveniles, although there is considerable doubt whether a surplus of prey exists to support a large walleye population. Bennett (1991) suggested that the limiting factors on the walleye population in the midColumbia reservoirs are recruitment and low turbidity.

Few smallmouth bass appear to be present within mid-Columbia reservoirs, probably because of low ambient water temperatures. Bennett (1991) identified water temperature as a limiting factor for smallmouth bass. Most of the smallmouth bass angling is concentrated in the mouth of the Chelan River. 
The Hanford Reach is unique because it represents the last free-flowing, yet regulated, stretch of the Columbia River remaining above Bonneville Dam. Discharges in the Hanford Reach are regulated by releases from Priest Rapids Dam. The minimum instream flow mandated by the Federal Energy Regulatory Commission (FERC) is $7,499 \mathrm{~m}^{3} / \mathrm{s}$ (Sneider and Skaggs 1983). The powerhouse hydraulic capacity at Priest Rapids Dam is $4,813 \mathrm{~m}^{3 / \mathrm{s}}$. Water levels in the Hanford Reach follow a diurnal cycle and may fluctuate several meters over the course of a day. These fluctuations in river flows and pool levels have profound effects on fish (Becker et al. 1981; Sneider and Skaggs 1983). Since 1943, when the federal government closed the Hanford Reservation to the general public, there has been no resident human population living along the Hanford Reach.

This 80 -iwn stretch of river from Priest Rapids Dam to the town of Richland has relatively little vertical relief and provides critical spawning habitat for a number of anadromous salmonid species (Rickard and Watson 1985). The Hanford Reach is characterized by a substrate of gravel, cobble, and rock. The main channel of the Reach includes a number of islands, which along with submerged rock ledges and gravel bars are remnants of former glaciation. The large material in the bed left behind by the glaciers acts as an armor layer, which maintains the main morphological features of the channel--a series of pools and crossings. The maximum rate of primary production in the Hanford Reach is low and comparable to the rate in unproductive oligotrophic lakes (Stober et al. 1979).

\subsubsection{Biodiversity}

Since 1943, forty-three species of fish representing 13 families have been collected from two locations within the Hanford Reach (Gray and Dauble 1977). These include mainly resident but also anadromous species. At least nine of the resident species were introduced from the eastern United States or Eurasia prior to 1940. Dauble and Page (1984) conducted studies of juvenile resident fish species in the Columbia River near $N$ Reactor during late summer 1983 using tyke nets on anchored barges, electroshocking gear, and gill nets. Largescale sucker were the most abundant resident species and they made up $47 \%$ of all the fish captured. Longnose dace, peamouth, carp, and northern squawish represented $14,13,5$, and $4 \%$ of the total catch, respectively.

Species of particular concern in the state of Washington, because they are low in abundance and found only in the Columbia River Basin, include the sandroller (Percopsis transmontana), mountain sucker (C. platyrhynchus), piute sculpin (C. beldingi), and reticulate sculpin (C. perplexus) (Johnson 1987). 


\subsubsection{Species-Specific Concerns}

The Hanford Reach is the only significant remaining section of the inland Columbia River where white sturgeon are able to spawn (Mullan et al. 1986). Although their habitat requirements within the Hanford Reach have not been studied specifically, probable spawning and rearing areas are dispersed throughout the entire reach (Fickeisen et al. 1980). Haynes and Gray (1981) documented the diel and seasonal movements of white sturgeon in the mid-Columbia River using radio-telemetry equipment. They found that temperature is a major influence stimulating long-distance (i.e., >2 km) seasonal movements, and that the light cycle and feeding probably influence diel movements. In addition, Haynes and Gray (1981) speculated that the urge to spawn also influenced seasonal movements.

Mountain whitefish occur throughout the entire Hanford Reach. Fluctuations in river flows that cause watering and dewatering of shallow-water areas are likely to impact both adult and juvenile mountain whitefish, as well as every other resident species in the Hanford Reach (Dauble, personal communication, 1993).

The sandroller is classified as a proposed monitor species in the state of Washington and is designated as a species of special concern because of its limited distribution (Johnson 1987). It is endemic to the Columbia River system but is currently found only in limited sections of the lower Columbia River including the Hanford Reach. Gray and Dauble (1976) documented the known distribution of sandrollers in the lower Columbia River and suggested that this species exhibits a diel activity pattern, based on SCUBA observations both during the day and at night. Little is known about the life history of this species.

Piute sculpin, reticulate sculpin, and mountain sucker are also listed as species of special concern in the state of Washington (Johnson 1987). Like the sandroller, these species are native to the Columbia River system and are found in relatively low abundance in the Hanford Reach (Gray and Dauble 1977). Rogers et al. (1989) conducted shoreline surveys above Priest Rapids Dam with a backpack electroshocker at monthly intervals from May through August 1988 specifically to try and capture piute and reticulate sculpins. Along both river shorelines, the only sculpin they collected was the prickly sculpin (Cottus asper).

Non-native resident fish include smallmouth and largemouth bass. Of the two species, smallmouth bass are more abundant in the Hanford Reach. Smallmouth bass were introduced into the Yakima River system around 1925 and they have dispersed throughout the Hanford Reach (Fickeisen et al. 1980). Adult smallmouth bass migrate to spawn in the warm backwaters of the Hanford Reach, and juveniles rear in these nutrient-rich, shallowwater environments. 
Another non-native resident fish species found in the Hanford Reach is walleye. Although not as common as smallmouth bass, walleye are occasionally caught by anglers in the Hanford Reach.

\subsubsection{Sport Fisheries}

Resident game fish species within the Hanford Reach include mountain whitefish, largemouth bass, channel catfish (Ictalurus punctatus), black crappie, smallmouth bass, walleye, white sturgeon, and bluegill (Lepomis macrochirus). Because smallmouth bass are especially vulnerable to sportfishing when they are concentrated in shallow water during spawning, fishing restrictions are enforced along the Hanford Reach to protect spawning bass from over-harvesting (Rickard and Watson 1985).

\subsection{COLUMBIA RIVER BELOW BONNEVILLLE DAM}

Based on conversations with Brad James of the Washington Department of Fisheries (personal communication, May 1993) and George McCabe of the National Marine Fisheries Service (personal communication, May 1993), there are few published studies that document resident fish utilization of the lower Columbia River below Bonneville Dam. The lower Columbia River is a unique remnant of pre-impoundment days because it is freeflowing from below Bonneville Dam to the Pacific Ocean.

In the following sections of this report, resident fish are defined as those species that stay in the river during all life stages. Thus, species that use the Columbia River estuary are not included in the discussion.

\subsubsection{Biodiversity}

Resident fish species that have been observed in the mainstem Columbia River below Bonneville Dam are summarized in Table 3.2. From March to October each year from 1988 to 1991, the National Marine Fisheries Service collected fish with a 7.9-m bottom trawl between river kilometer 46 and 211 (George McCabe, personal communication, October 1993). The data for the 4 years are pooled in Table 3.2. Of the 16 species listed in Table 3.2, white sturgeon, peamouth, largescale suckers, and northern squawtish were the most abundant.

\subsubsection{Species-Specific Concerns}

The Columbia River, downstream of Bonneville Dam, supports large populations of migrating juvenile salmonids as well as large populations of white sturgeon (DeVore et al. 1992). White sturgeon are of particular concern because, in relation to the whole Columbia River basin, they are most abundant in the lower Columbia River downstream from Bonneville Dam (DeVore et al. 1992), and because they constitute a unique naturally 
IABLE 3.2. Resident Fish Species Collected with a 7.9-m Bottom Trawl in the Lower Columbia River Between River Kilometer (RKm) 46 and 211 from 1988 to 1991 (Unpublished data provided by George McCabe, NMFS, 1993)

Common Name (Scientific Name)

River lamprey

(Lampetra ayresi)

Pacific lamprey

(Lampetra tridentata)

White sturgeon

(Acipenser transmontanus)

Chiselmouth

(Acrocheilus alutaceus)

Common carp

(Cyprinius carpio)

Peamouth

(Mylocheilus caurinus)

Northern squawish

(Ptychochelius oregonensis)

Leopard dace

(Rhinichthys falcatus)

Redside shiner

(Richardsonius balteatus)

Largescale sucker

(Catostomus macrocheilus)

Mountain whitefish

(Prosopium williamsoni)

Sandroller

(Percopsis transmontana)

Smallmouth bass

(Micropterus dolomieu)

Black crappie

(Pomoxis nigromaculatus)

Yellow perch

(Perca flavescens)

Walleye

August, (Stizostedion vitreum)

No. Captured Range (RKm) Menths of Capture

\section{2}

30

150

1

204

3,743

1,449

161

10

1,620

3

277

1

5

11

8
46-89

46-212

$43-218$

205

98-211

$38-217$

$38-213$

$107-218$

$142-211$

43-212

211

$82-212$

183

$120-162$

$82-211$

$153-212$
April, May

March-June

March-October

October

March-October

March-October

March-October

March-October

May-August, October

March-October

March, April

March-October

August

August-October

July-October

May, July, October 
reproducing remnant stock. Concerns about potential impacts to white sturgeon from the proposed system operating strategies are being addressed by the Anadromous Fish Work Group.

\subsubsection{Sport Fisheries}

A small sport fishery exists for smallmouth bass and yellow perch, and a sport fishery for walleye is gaining interest as the stocks of this introduced species become established in the lower Columbia River. However, based on the data presented in Table 3.2, none of these three species is very abundant. During the four-year NMFS survey, only 1 smallmouth bass, 11 yellow perch, and 8 walleye were collected. A reward fishery for northern squawfish has been instituted in the lower Columbia River, because of their documented predation on salmon stocks.

\subsection{SNAKE RIVER BELOW HELLS CANYON DAM}

The Snake River from below Hells Canyon Dam to lower Granite Dam is one of the last free-flowing sections of this river in the Columbia River Basin. Hells Canyon Dam, constructed in 1967 by the Idaho Power Company, is the most recent of a series of three dams built upstream of Hells Canyon. This section of the Snake River flows $224.5 \mathrm{~km}$ through a semiarid region characterized by steep basalt slopes with steppe vegetation. This river stretch contains rapids interspersed with long stretches of deep water that moves slowly over a substrate composed of bedrock, rock rubble, or sand (Munther 1967). Most of this river section flows through Hells Canyon, the deepest canyon in North America.

The Snake River flow is augmented by three major tributaries (Grande Ronde River, Salmon River, and Imnaha River) that improve the water quality received from the upstream reservoirs. For the years 1982 to 1984 , streamflow ranged from 649 to $3,789 \mathrm{~m}^{3 / \mathrm{s}}$ with an average of $1,603 \mathrm{~m} 3 / \mathrm{s}$ at Anatone, Washington, and from 362 to $1,948 \mathrm{~m} 3 / \mathrm{s}$ with an average of $935 \mathrm{~m} 3 / \mathrm{s}$ at Hells Canyon Dam (Lukens 1985). Water temperature measured at the Antone, Washington, gaging station typically ranges from 6 to $25^{\circ} \mathrm{C}$. The stream gradient for the upper river section, defined as Rkm 289.9 to the Hells Canyon Dam (Rkm 397.4), is fairly constant and averages $1.8 \mathrm{~m} / \mathrm{km}$. Downstream of this stretch, the stream gradient decreases to an average of $0.7 \mathrm{~m} / \mathrm{km}$ (Lukens $1984,1985,1986$ ).

\subsubsection{Biodiversity}

Resident sport fish in the Snake River below Hells Canyon Dam include white sturgeon, smallmouth bass, rainbow trout, channel catfish, mountain whitefish, northern squawfish, largescale sucker, redside shiner, chiselmouth, peamouth, black crappie, carp, bullhead catfish, and American shad. 
Fish samples collected by trapping during 1955 and 1956 indicated that $15 \%$ were game fish, with channel catfish and white sturgeon being the most abundant, and $85 \%$ were non-game fish (USFWS 1964).

\subsubsection{Species-Specific Concerns}

The few remaining Redfish Lake sockeye salmon (Oncorhyncus nerka), which are listed as endangered species under the ESA, migrate through the Hells Canyon section of the Snake River. Fall chinook salmon and steelhead smolts and adults also pass through this section of the river.

A limited fall/summer chinook escapement occurs above the confluence of the Salmon River. There is concern that smallmouth bass may consume 0 -age fall/summer chinook smolts because an estimated $50 \%$ of the smallmouth bass diet is composed of smolts during the annual fall/summer chinook outmigration (Ed Schriever, personal communication, June 1993).

American shad have been observed spawning in the confluence of the Snake and Clearwater Rivers and the possible impacts of this exotic species, as well as others, on resident fish is unknown at the present (Ed Schriever, personal communication, June 1993). The presence of American shad in the Snake River represents an extension of their former range.

Mortality of sport fish at Hells Canyon has been reported following periods of long spills; the observed mortality was attributed primarily to lethal levels of gas supersaturation (Lukens 1986).

\subsubsection{Sport Fișheries}

Steelhead are the preferred sport fish species, but smallmouth bass are the species most readily hooked. Chinook salmon, rainbow trout, and sturgeon are also caught below Hells Canyon Dam (Welsh and Reid 1970). During 1969, the section below Hells Canyon Dam received 85,138 angler hours of fishing pressure (Welsh and Reid 1970). According to Schriever (personal communication, June 1993), there has been a recent increase in fishing pressure on all sport fish species.

The Hells Canyon Reach of the Snake River is the most popular location in Idaho to fish for white sturgeon. In this reach, there is a well-defined age class of adult fish, as well as a large number of juvenile fish. An increasing number of anglers are participating in the white sturgeon fishery, and approximately $70 \%$ of the anglers sampled have taken up the sport in the last 5 years (Ed Schriever, personal communication, June 1993). Since 1970, the white sturgeon sport fishery in the Hells Canyon Reach of the Snake River has been 
managed as a catch-and-release fishery (Lukens 1984, 1985). Prior to 1970, harvest was allowed only on sturgeon $91.5 \mathrm{~cm}$ to $183 \mathrm{~cm}$. Since termination of this harvest, mean length at age has increased, condition has improved, and handling mortality has decreased (Lukeris 1985). Although barbless hooks have been required in Hells Canyon since 1972, repeat catches on sturgeon are common based on the number of visible hook scars on the fish. An occasional $3.5 \mathrm{~m}$ sturgeon is still caught by sportfishermen (Ed Schriever, personal communication, June 1993).

The area of the Snake River between the mouth of the Salmon River and Asotin, Washington, and the upstream end of Lower Granite pool are presumed to be important juvenile sturgeon rearing areas (Lukens 1985). Bennett et al. (1993) estimated that $93 \%$ of the sturgeon sampled during 1991 in Lower Granite Reservoir were juveniles (>125 cm total length) and that the upper third of the reservoir was preferred by these juvenile sturgeon based on higher mean catch rates. An estimated 3,955 white sturgeon, $45 \mathrm{~cm}$ to $280 \mathrm{~cm}$ in length, inhabited the Snake River between Lewiston and Hells Canyon Dam during 1984 (Lukens 1985). Coon (1978) was less conservative and estimated that 8,000 to 12,000 white sturgeon greater than $45 \mathrm{~cm}$ in length inhabitated the Snake River from Lower Granite Dam upstream to Hells Canyon Dam during the period 1973 to 1975.

Crappie fishing is popular below Hells Canyon Dam, especially during late spring when outflow from Hells Canyon Dam is around $15,625 \mathrm{~m}^{3} / \mathrm{s}$. However, this fishery is dependent upon recruitment from Hells Canyon and Brownlee reservoirs (Lukens 1986). The lack of submerged vegetation available for spawning or cover might be a limiting factor for crappie populations below Hells Canyon Dam.

Rainbow trout fishing from below Hells Canyon Dam to Pittsburgh Landing is exceptional, due primarily to residualized steelhead smolts. Around 750,000 steelhead smolts are outplanted yearly below Hells Canyon Dam and approximately $99 \%$ of the rainbow trout harvest above the Salmon River confluence is composed of residual hatchery steelhead from this outplanting (Ed Schriever, personal communication, June 1993).

Smallmouth bass were introduced into the river in the late 1800s and have become well established (Munther 1967). There is a popular sport fishery for smallmouth bass in the lower section of the Hells Canyon Reach from below the Grande Ronde River to the town of Lewiston. Bass fishing is still considered to be excellent in this area, and increased angler exploitation has not yet limited the size structure of smallmouth bass (Ed Schriever, personal communication, June 1993).

A channel catfish sport fishery exists, but recruitment is limited by temperature. The majority of channel cattish are entrained from the three reservoirs above Hells Canyon Dam, as demonstrated by the high CPUE observed for channel catfish in the upper canyon with 
a decreasing trend in CPUE downstream of Hells Canyon Dam (Ed Schriever, personal communication, June 1993).

Bull trout are found in limited numbers in Hells Canyon. Adult and juvenile bull trout are well documented in two tributaries to the Hells Canyon Reach--Granite and Sheep Creeks. Bull trout have also been documented in sport fish catches in upper Hells Canyon, the mouth of the Salmon River, the mouth of Wolf Creek, and the mouth of the Grande Ronde River (Ed Schriever, personal communication, November 1993). 


\subsection{POTENTIAL IMPACTS TO RESIDENT FISH FROM THE SEVEN PROPOSED SYSTEM OPERATING STRATEGIES}

Predictions of the qualitative impacts to resident fish from the 7 SOSs proposed in the SOR were constrained by the lack of hydroregulated flows or elevations for certain reservoirs (Table 4.1). Because of this constraint, no assessment of impacts was made for the Clark Fork River, the Pend Oreille River, or the Snake River below Hells Canyon Dam. Another major constraint was the lack of requisite information on daily operations at certain critical dams. Information on daily, or even hourly, flow fluctuations is necessary in order to determine potential impacts at the mid-Columbia projects and the Hanford Reach.

In general, our data were less sensitive to changes in SOSs than to daily flow fluctuations. Most of the SOSs seem to be moving the Columbia River system away from base flows and toward peaking flows. Unpredictable flows that result from peaking power operations are especially detrimental to resident fish. Peaking flows can result in entrainment of resident fish; watering/dewatering of spawning, rearing, and feeding habitat; gas supersaturation; and extreme temperature fluctuations. Hourly fluctuations in instream flow are perhaps the major limiting factor for resident fish species in the Clark Fork River below Cabinet Gorge Dam, the mid-Columbia River, and the Hanford Reach.

The SOS that is predicted to have the fewest impacts on resident fish is SOS-4, because it minimizes storage reservoir fluctuations while moving the Columbia River system closer to natural flow conditions at the run-of-river projects.

\subsection{CANADIAN PROJECTS}

\subsubsection{Kinbasket Reservoir, Arrow Lakes, and Kootenay Lake}

Based on an assessment of the 7 proposed SOSs, Catherine Gee (Department of Fisheries and Oceans, unpublished, 1993) developed the following list of potentialimpacts to resident fish within Kinbasket Reservoir, Arrow Lakes, and Kootenay Lake:

- Entrainment of fish occurs because of high flows and as fish pass either through a dam's turbines or over its spillway or gates.

- There is a loss of nearshore habitat because of drawdown.

- There is decreased angling effort when the reservoir is drawn down because of fewer usable boat access points.

- Flooding of spring spawning areas in tributaries occurs because of yearly reservoir filling.

- Debris in the reservoir can block access to spawning streams as the reservoir water level is drawn down.

- Seasonal reservoir levels may block access to spawning areas. 
TABLE 4.1. Summary of SOS Comparisons for Non-Modeled Projects

\begin{tabular}{|c|c|c|c|c|}
\hline $\begin{array}{l}\text { Project Name } \\
\text { (Dam) }\end{array}$ & $\begin{array}{l}\text { Key Resident } \\
\text { Fish Species } \\
\end{array}$ & $\begin{array}{c}\text { Hydroregulated } \\
\text { Data }\end{array}$ & $\begin{array}{c}\text { Hydroreg } \\
\text { Comparison } \\
\end{array}$ & $\begin{array}{l}\text { Other } \\
\text { Hydrology }\end{array}$ \\
\hline $\begin{array}{l}\text { Kinbasket Reservoir } \\
\text { (Mica Dam) }\end{array}$ & $\begin{array}{l}\text { Mountain } \\
\text { whitefish, bull } \\
\text { trout, rainbow } \\
\text { trout, burbot, } \\
\text { kokanee }\end{array}$ & $\begin{array}{l}\text { Flows and } \\
\text { elevations } \\
\text { at Mica Dam }\end{array}$ & $\begin{array}{l}\text { Elevs: all SOSs } \\
\text { exactly same } \\
\text { Flows: all same } \\
\text { ex'ept SOS1 }\end{array}$ & $\begin{array}{l}\text { Not readily } \\
\text { available }\end{array}$ \\
\hline $\begin{array}{l}\text { Arrow Lakes } \\
\text { (Keenleyside Dam, } \\
\text { also called Arrow } \\
\text { Dam) }\end{array}$ & $\begin{array}{l}\text { Rainbow trout, } \\
\text { bull trout, } \\
\text { kokanee, mountain } \\
\text { whitefish }\end{array}$ & $\begin{array}{l}\text { Flows and } \\
\text { elevations at } \\
\text { Arrow Dam }\end{array}$ & $\begin{array}{l}\text { Elevs and flows: } \\
\text { SOS1,4 same; } \\
\text { SOS2,3,5,6,7b,7c } \\
\text { same; SOS7a } \\
\text { slightly different }\end{array}$ & $\begin{array}{l}\text { Not readily } \\
\text { available }\end{array}$ \\
\hline $\begin{array}{l}\text { Kootenay Lake } \\
\text { (Corra Linn Dam) }\end{array}$ & $\begin{array}{l}\text { Rainbow trout, } \\
\text { bull trout, } \\
\text { kokanee, } \\
\text { mountain } \\
\text { whitefish, burbot }\end{array}$ & $\begin{array}{l}\text { Flows and } \\
\text { elevations at } \\
\text { Corra Linn Dam }\end{array}$ & $\begin{array}{l}\text { Elevs: SOS2,5, } \\
\text { 6,7b,7c same; SOS1, } \\
3,4 \text { same; SOS7a } \\
\text { slightly different } \\
\text { Flows: SOS3,4 } \\
\text { same; SOS5,6 } \\
\text { same; SOS1,2 } \\
\text { same }\end{array}$ & $\begin{array}{l}\text { Not readily } \\
\text { available }\end{array}$ \\
\hline \multirow[t]{2}{*}{$\begin{array}{l}\text { Flathead Lake } \\
\text { (Kerr Dam) }\end{array}$} & \multirow[t]{2}{*}{$\begin{array}{l}\text { Kokanee, yellow } \\
\text { perch, mountain } \\
\text { whitefish, lake } \\
\text { trout, largemouth } \\
\text { bass, bull trout, } \\
\text { cutthroat trout }\end{array}$} & $\begin{array}{l}\text { Flows at } \\
\text { Columbia Falls } \\
\text { on the Flathead } \\
\text { River ( } 32-40 \mathrm{~km} \\
\text { upstream of lake) }\end{array}$ & $\begin{array}{l}\text { Flows: SOS1; } \\
\text { SOS2,3,5,6,7 } \\
\text { same; SOS4 }\end{array}$ & \multirow[t]{2}{*}{$\begin{array}{l}\text { Yes, in } \\
\text { Flathead } \\
\text { River system }\end{array}$} \\
\hline & & $\begin{array}{l}\text { Flows and } \\
\text { elevations at } \\
\text { Kerr Dam }\end{array}$ & $\begin{array}{l}\text { Elevs: all same } \\
\text { Flows: SOS1,2 } \\
3,5,6,7 b, 7 c \text { approx. } \\
\text { same; SOS4a, } 4 b, 7 a \\
\text { slightly different }\end{array}$ & \\
\hline
\end{tabular}


TABLE 4.1. (contd)

\begin{tabular}{|c|c|}
\hline $\begin{array}{l}\text { Project Name } \\
\text { (Dam) }\end{array}$ & $\begin{array}{l}\text { Key Resident } \\
\text { Fish Species }\end{array}$ \\
\hline $\begin{array}{l}\text { Clark Fork River } \\
\text { (Below Cabinet Gorge } \\
\text { Dam) }\end{array}$ & $\begin{array}{l}\text { Bull trout, } \\
\text { brown trout, } \\
\text { cutthroat trout, } \\
\text { rainbow trout, } \\
\text { kokanee }\end{array}$ \\
\hline
\end{tabular}

Hydroregulated Data

None

None

Pend Oreille River (Below Albeni Falls Dam)

Lake Rufus Woods/ (Columbia River Chief Joseph Dam)

\section{$\mathscr{\omega}$} largemouth bass,

tench, brown

N. squawfish,

peamouth, suckers,

kokanee (from

Grand Coulee)
Hydroreg Comparison

Not applicable Hydrology

Yes

Yes

trout, $n$. squawfish

Walleye, white

sturgeon, mountain

whitefish,

suckers, stickle

backs, n. squawfish,

channel catfish

White sturgeon,

smallmouth bass,

mountain whitefish,

sandrollers (state

sensitive),

suckers, sculpins
Flows and

elevations at

Chief Joseph

Dam

Flows

Flows at Priest Rapids Dam
Not applicable

Elevs: All same

Flows: SOS1,2,

5,6,7 approx.

same; SOS3;

SOS4

Flows: all SOSs very similar for

all projects, only

slight differences

in SOS 3,4 and $7 a$

Flows: all SOSs

very similar, only

slight differences

in SOS3,4 and 7a
No gaging

except at

Priest

Rapids Dam
Yes

Y'es

Yes 
TABLE 4.1. (contd)

\begin{tabular}{|c|c|c|c|c|}
\hline $\begin{array}{l}\text { Project Name } \\
\text { (Dam) }\end{array}$ & $\begin{array}{l}\text { Key Resident } \\
\text { Fish Species }\end{array}$ & $\begin{array}{c}\text { Hydroregulated } \\
\text { Data }\end{array}$ & $\begin{array}{l}\text { Hydroreg } \\
\text { Comparison }\end{array}$ & $\begin{array}{c}\text { Other } \\
\text { Hydrology }\end{array}$ \\
\hline $\begin{array}{l}\text { Columbia River below } \\
\text { (Below Bonneville Dam) }\end{array}$ & $\begin{array}{l}\text { White sturgeon, } \\
\text { walleye, } \\
\text { smallmouth bass, } \\
\text { largemouth bass }\end{array}$ & $\begin{array}{l}\text { Flows at } \\
\text { Bonneville Dam }\end{array}$ & $\begin{array}{l}\text { Flows: all SOSs } \\
\text { very similar, only } \\
\text { slight differences } \\
\text { in SOS3 and SOS4 }\end{array}$ & Yes \\
\hline $\begin{array}{l}\text { Hells Canyon Reach } \\
\text { of the Snake River } \\
\text { (Below Hells Canyon } \\
\text { Dam) }\end{array}$ & $\begin{array}{l}\text { White sturgeon, } \\
\text { smallmouth bass, } \\
\text { rainbow trout, } \\
\text { channel catfish, } \\
\text { mountain whitefish }\end{array}$ & None & Not applicable & Yes \\
\hline
\end{tabular}


As identified by Gee, the impacts at Kinbasket Reservoir, Arrow Lakes, and Kootenay Lake predicted above are not linked to any specific system operating strategy. Gee notes that an understanding of the impacts to resident fish from Columbia River hydroelectric operations is further confounded by the operation of hydroelectric projects on the Peace River. Bennett Dam and Peace Canyon Dam, both owned and operated by B.C. Hydro, are used to offset power generation when conditions in the Columbia/Kootenay systems are not conducive to efficient power generation. Hence, potential fishery impacts associated with these dams are tied into U.S. Columbia River system operations.

\subsection{FLATHEADLAKE}

Based on the similarities between the flows and elevations for all SOSs (except SOS-4), impacts to resident fish from each of the 7 SOSs are expected to be similar. However, it is not obvious whether these impacts will be different from those of current operations. With the exception of stable reservoir elevations at Hungry Horse Dam and a return to a more natural outflow under SOS-4, all other operations will probably not alleviate the impacts to kokanee salmon. Currently, the primary impact to resident fish in Flathead Lake is lake level fluctuations caused by the independent operation of Hungry Horse and Kerr dams. Shoreline spawners in Flathead Lake are negatively impacted by lake level fluctuations caused by Kerr Dam, and Upper Flathead River spawners are negatively impacted by peaking power operations at Hungry Horse Dam.

\subsection{CLARK FORK RIVER BELOW CABINET GORGE DAM}

No determination of impacts is possible because no information on hydroregulated flows or elevations is available for this location. In addition, estimates of abundance, distribution, the timing of spawning, and food habits of resident fish populations in this location are poorly documented. Peaking power operations at Cabinet Gorge Dam that result in extreme daily fluctuations in flow (range: $425 \mathrm{~m}^{3} / \mathrm{s}$ to $85 \mathrm{~m}^{3} / \mathrm{s}$ ) are currently the primary limiting factor for resident fish species within the Clark Fork River.

\subsection{PEND OREILLE RIVER BELOW ALBENI FALLS DAM}

No determination of impacts is possible because there is no information on hydroregulated flows or elevations for this location. Under existing operations at Albeni Falls Dam, resident fish populations in the Pend Oreille River are adversely affected by fluctuating surface elevations and water temperatures that affect growth and the timing of spawning. Impacts from existing operations to cutthroat and bull trout spawning and largemouth bass 
recruitment are of particular concern. Non-game species likely to be negatively impacted by present operations are northern squawfish, tench, and largescale sucker.

\subsection{LAKE RUFUS WOODS AND COLUMBIA RIVER BELOW CHIEF JOSEPH DAM}

Hydroregulated elevations at Chief Joseph Dam are identical for all SOSs $(293 \mathrm{~m})$, suggesting that impacts to resident fish resulting from each SOS are likely to be similar. Lake Rufus Woods acts as a run-of-river reservoir, and the impacts to resident fish at this location are likely to be similar to those in Lake Roosevelt (the reservoir for Grand Coulee Dam). Impacts resulting from Grand Coulee Dam operations are loss of nutrients, loss of zooplankton, loss of benthic invertebrates, decreases in fish spawning and feeding habitats, and entrainment losses of kokanee and rainbow trout. Nearly all of the alternatives presented in the hydroregulated analyses are poor for resident fish in Lake Roosevelt, and thus it is assumed that the impacts to resident fish in Lake Rufus Woods would be similar.

\subsection{MID-COLUMBIA RIVER}

No hydroregulated elevations are available for any of the five reservoirs formed by the mid-Columbia run-of-river facilities (Wells, Rocky Reach, Rock Island, Wanapum, and Priest Rapids reservoirs). The resident fish species within these five reservoirs have not been well studied. These reservoirs currently function primarily as coldwater tailwaters to the Grand Coulee Dam storage reservoir (Lake Roosevelt). Hydroregulated flows are nearly the same for all SOSs at the mid-Columbia projects. Temperature and high water velocities (low water retention time) are most likely the primary factors limiting the success of resident fish species throughout the mid-Columbia reservoirs.

Any of the SOSs that result in reduced spring and summer water temperatures would severely limit the spawning opportunities for non-native warmwater species such as sunfish, bass, and catfish that can spawn only in warm backwaters. It is unclear to what extent the 7 SOSs will maintain stable flows in the mid-Columbia, but high water velocities are likely to result in decreased resident fish populations because of gas supersaturation and entrainment of resident species through the dam turbines.

\subsection{HANFORD REACH}

No determination of specific impacts from the 7 SOSs proposed is possible because the majority of the impacts occur in shorter time frames (i.e., hourly) than the available information on present operating conditions. Water surface elevations within the Hanford Reach are not available, and hydroregulated flows are only available at monthly intervals. This makes the assessment of any impacts speculative. 
Although the Hanford Reach is un-impounded, the flows and fluctuating water levels are highly influenced by operation of Priest Rapids Dam. Fluctuations in water level may exceed $3 \mathrm{~m}$ in a single day. Extreme hourly to daily fluctuations significantly impact the spawning and incubation, rearing, and overwinter survival of nearly all resident fish that inhabit the Hanford Reach. Rapid fluctuations in water level are also likely to strand many resident fish species that typically inhabit nearshore areas (e.g., mountain whitefish fry, sculpin adults and eggs). Smallmouth bass presently spawn in the shallow backwater sloughs of the Hanford Reach. Extreme water surface fluctuations would potentially either displace adult bass from their spawning nests and/or impact newly emergent fry, that are very dependent upon stable and warm water in which to feed. Species such as sturgeon and mountain whitefish are dependent upon adequate velocities in order to successfully spawn. Because sturgeon are pelagic spawners, typically with demersal eggs, impacts to them will probably be limited to effects on their preferred spawning velocities. Species of special concern, including the sandroller, mountain sucker, piute sculpin, and reticulate sculpin are all dependent on stable river flows. The operation of Priest Rapids Dam to resemble natural river flows will likely favor all resident fish species.

\subsection{COLUMBIA RIVER BELOW BONNEVILLE DAM}

The primary constraint in assessing impacts below Bonneville Dam is the lack of published studies documenting the abundance and distribution of resident fish and the lack of hydroregulated surface water elevations downstream of Bonneville Dam. Approximately $90 \%$ of the sportfishing effort in the lower Columbia River is directed toward anadromous species. Resident fish species have not received much attention in this stretch of the river. The principal species of concern is the white sturgeon and the impacts to white sturgeon are being evaluated by the SOR Anadromous Fish Work Group.

\subsection{SNAKE RIVER BELOW HELLS CANYON DAM}

No determination of impacts is possible because there is no information on hydroregulated flows or elevations for this location. In the Snake River below Hells Canyon Dam, white sturgeon and rainbow trout (residualized steelhead) are the principal resident fish species of concern. Under current operations, mortality of resident fish species resulting from gas supersaturation has been reported below Hells Canyon Dam following periods of long spills (Lukens 1986). In addition, flow fluctuations have the potential to impact resident fish downstream. 


\subsection{REFERENCES}

Ash, G., L. Corkum, and W. Luedke. 1982. Fisheries Inventory and Impact Assessment for the Proposed Keenleyside Power Plant Project on the Columbia River. B.C. Final report prepared for B.C. Hydro by R.L. \& L. Environmental Services Ltd., Edmonton, Alberta.

Ashe, B.L., K.L. Lillengreen, J.J. Vella, L.O. Clark, S. Graves, M.R. Barber, G.J. Nenema, Jr., and A.T. Scholz. 1991. Assessment of the Fishery Improvement Opportunities on the Pend Oreille River. DOE/BP-39339-4, Bonneville Power Administration, Portland, Oregon.

Ashley, K., and L. Thompson. 1993. Kootenay Lake Fertilization Experiment Year 1 (1992/1993) Report. Fisheries Research and Development Section, University of British Columbia, Vancouver, British Columbia.

Beattie, W., P. Clancy, and R. Zubik. 1988. Effect of the Operation of Kerr and Hungry Horse Dams on the Reproductive Success of Kokanee in the Flathead System. DOE/BP-39641-5, Bonneville Power Administration, Portland, Oregon.

Becker, C.D., D.H. Fickeisen, and J.C. Montgomery. 1981. Assessment of Impacts from Water Level Fluctuations on Fish in the Hanford Reach. Columbia River. PNL-3813, Pacific Northwest Laboratory, Richland, Washington.

Bennett, D.H. 1991. Potential for Predator Increase Associated with a Three Foot Pool Rise in Rocky Reach Reservoir, Columbia River, Washington. Prepared for Public Utility District No. 1 of Chelan County, Wenatchee, Washington.

Bennett, D.H., and M. Liter. 1991. Water Quality, Fish and Wildlife Characteristics of Box Canyon Reservoir. Washington. Section 3: Fish. Department of Fish and Wildlife Resources, College of Forestry, Wildlife and Range Sciences, University of Idaho, Moscow, Idaho.

Bennett, D.H., T.J. Dresser, Jr., T.S. Curet, D.B. Lepla, and M.A. Madsen. 1993. Monitoring Fish Community Activity at Disposal and Reference Sites in Lower Granite Reservoir, IdahoWashington Year 4 (1991). Prepared for U.S. Army Corps of Engineers-Walla Walla District, Walla Walla, Washington.

BPA. 1991. The Columbia River System: The Inside Story. DOE/BP-1689, Bonneville Power Administration, Portland, Oregon.

Coon, J. C. 1978. Movement. Distribution, Abundance, and Growth of White Sturgeon in the Mid-Snake River. Ph.D. Thesis, University of Idaho, Moscow, Idaho.

Cross, D., and I. Waite. 1988. Lower Flathead System Fisheries Study: South Bay of Flathead Lake, Volume III. DOE/BP-39830-3, Bonneville Power Administration, Portland, Oregon.

Dauble, D.D., and T.L. Page. 1984. Fish Distribution Studies Near N Reactor, Summer 1983. UNI-2754, Pacific Northwest Laboratory, Richland, Washington.

Dell, M.B., M.W. Erho, and B.D. Leman. 1975. Occurrence of Gas Bubble Disease Symptoms of Fish in Mid-Columbia River Reservoirs. Public Utility Districts of Grant, Douglas, and Chelan Counties, Ephrata, Washington. 
DeVore, J. D., B. W. James, and D. Hale. 1992. "Dynamics and Potential Production of the White Sturgeon Population in the Columbia River Downstream from Bonneville Dam". In Status and Habitat Requirements of the White Sturgeon Populations in the Columbia River Downstream from McNary Dam, Volume I, eds. R. C. Beamesderfer and A. A. Nigro. Final report (Contract DE-Al79-86BP63584) to Bonneville Power Administration, Portland, Oregon.

Fickeisen, D.H., R.E. Fitzner, R.H. Sauer, and J.L. Warren. 1980. Wildlife Usage, Threatened and Endangered Species and Habitat Studies of the Hanford Reach, Columbia River. Washington. Prepared for the U.S. Army Corps of Engineers, Seattle District, Washington, by Battelle, Pacific Northwest Laboratories, Richland, Washington.

Fraley, J.J., and B.B. Shepard. 1989. "Life History, Ecology and Population Status of Migratory Bull Trout (Salvelinus confluentus) in the Flathead Lake and River System, Montana." Northwest Science 63:133-143.

Fraley, J.J., B. Marotz, J. Decker-Hess, W. Beattie, and R. Zubik. 1989. "Mitigation, Compensation, and Future Protection for Fish Populations Affected by Hydropower Development in the Upper Columbia System, Montana, U.S.A." Regulated Rivers: Research \& Management 3:3-18.

Gray, R.H., and D.D. Dauble. 1976. "New Distribution Records and Notes on Life-History and Behavior of the Sand Roller, Percopsis transmontana." Syesis 9:369-370.

Gray, R.H., and D.D. Dauble. 1977. "Checklist and Relative Abundance of Fish Species from the Hanford Reach of the Columbia River." Northwest Science 51(3):208-215.

Haynes, J.M., and R.H. Gray. 1981. "Diel and Seasonal Movements of White Sturgeon, Acipenser transmontanus, in the Mid-Columbia River." Fishery Bulletin 79(2):367-370.

Hirst, S.M. 1991. "Impacts of the Operation of Existing Hydroelectric Developments on Fishery Resources in British Columbia, Volume III: Inland Fisheries." Canadian Manuscript Report of Fish and Aquatic Sciences 2093:200

Johnson, J.E. 1987. Protected Fishes of the United States and Canada. American Fisheries Society, Bethesda, Maryland.

Korman, J., C.J. Perrin, and R.C. Weigand. 1990. The Feasibility of Fertilization of Kootenay Lake. North Arm. Contract report prepared by Limnotek Research and Development, Inc. for Ministry of Environment, Nelson, British Columbia.

Lukens, J. R. 1984. Hells Canyon White Sturgeon Investigations. Job Performance Report, Project F-73-R-6, Idaho Department of Fish and Game, Boise, Idaho.

Lukens, J. R. 1985. Hells Canyon White Sturgeon Investigations. Job Performance Report, Project F-73-R-7, Idaho Department of Fish and Game, Boise, Idaho.

Lukens, J. R. 1986. Hells Canyon Resident Game Fish Investigations. Job Performance Report, Project F-73-R-8, Idaho Department of Fish and Game, Boise, Idaho.

Maiolie, M.A., J.A. Davis, and N. Horner. 1991. Federal Aid in Fish Restoration Job Performance Report: Project F-71-R-14. Idaho Department of Fish and Game, Coeur d'Alene, Idaho.

Marnell, L.F., R.J. Behnke, and F.W. Allendorf. 1987. "Genetic Identification of Cutthroat Trout, Salmo clarki, in Glacier National Park, Montana." Canadian Journal of Fisheries and Aquatic Sciences 44:1830-1839. 
Mullan, J.W., M.B. Dell, S.G. Hays, and J.A. McGee. 1986. Some Factors Affecting Fish Production in the Mid-Columbia River 1934-1983. U.S. Fish \& Wildlife Service Report No. FRI/FAO-86-15, U.S. Fish \& Wildlife Service, Leavenworth, Washington.

Munther, G. L. 1967. Movement and Distribution of Smallmouth Bass (Micropterus dolomieu) in the Middle Snake River. Master's Thesis, University of Idaho, Moscow, Idaho.

RFWG. 1993. Resident Fish Work Group Technical Appendix: Columbia River System Operation Review Environmental Impact Statement. Bonneville Power Administration, Portland, Oregon.

Rickard, W.H., and D.G. Watson. 1985. "Four Decades of Environmental Change and Their Influence upon Native Wildlife and Fish on the Mid-Columbia River, Washington, USA." Environmental Conservation 12(3):241-248.

R. L. \& L. Environmental Services Ltd. 1992. Mica Compensation Program Fisheries Management Plan. Prepared for Mica Compensation Program Fisheries Technical Committee by R.L. \& L. Environmental Services Ltd., Vancouver, British Columbia.

Rogers, L.E., P.A. Beedlow, L.E. Eberhardt, D.D. Dauble, and R.E. Fitzner. 1989. Ecological Baseline Study of the Yakima Firing Center Proposed Land Acquisition: A Status Report. PNL-6485, Pacific Northwest Laboratory, Richland, Washington.

Sebastian, D.C., and G. Scholten. 1993. Kokanee Stock Monitoring in Mica and Revelstoke Reservoirs: Results of Hydroacoustic Surveys in October 1991 and 1992. Conservation Section, Fisheries Branch, Ministry of Environment, Lands and Parks, Victoria, British Columbia.

Sneider, S.C., and R.L. Skaggs. 1983. Unsteady Flow Model of Priest Rapids Dam Releases at Hanford Reach, Columbia River, Washington. PNL-4527, Pacific Northwest Laboratories, Richland, Washington.

Spencer, C.N., B.R. McClelland, and J.A. Stanford. 1991. "Shrimp Stocking, Salmon Collapse, and Bald Eagle Displacement: Cascading Interactions in the Food Web of a Large Aquatic Ecosystem." BioScience 41:14-21.

Stanford, J.A., and B.K. Ellis. 1988. "Water Quality: Status and Trends." In Our Clean Water--Flathead's Resource of the Future. Proceedings of a Water Quality Conference. April 25-26. 1988. Kalispell, Montana. Flathead Basin Commission, Governor's Office, Helena, Montana.

Stanford, J.A., and F.R. Hauer. 1992. "Mitigating the Impacts of Stream and Lake Regulation in the Flathead River Catchment, Montana, USA: An Ecosystem Perspective." Aquatic Conservation: Marine and Freshwater Ecosystems 2:35-63.

Stanford, J.A., T.J. Stuart, and B.K. Ellis. 1983. Limnology of Flathead Lake. Flathead River Basin Environmental Impact Study, U.S. Environmental Protection Agency, Helena, Montana.

Stober, Q.L., M.R. Griben, R.V. Walker, A.L. Setter, I. Nelson, J.C. Gislason, R.W. Tyler, and E.O. Salo. 1979. Columbia River Irrigation Withdrawal Environmental Review: Columbia River Fisheries Study. Final Report No. DACW 57-79-C-0090, U.S. Army Corps of Engineers, Portland, Oregon.

Stuber, R.J., G. Gebhart, and O.E. Maughan. 1982. Habitat Suitability Index Models: Largemouth Bass. FWS/OBS-82/10.16, U.S. Fish \& Wildlife Service, Olympia, Washington. 
USFWS. 1964. A Survey of the Fish and Wildlife Resources of the Middle Snake River Basin. Idaho. Oregon and Washington. U.S. Department of the Interior, Fish and Wildlife Service, Olympia, Washington.

Welsh, T.L., and W.W. Reid. 1970. Hells Canyon Fisheries Investigation: Annual Completion Repert. Idaho Fish and Game Department, Boise, Idaho. 


\section{DISTRIBUTION}

No. of

Copies

\section{OFFSITE}

12 DOE/Office of Scientific and Technical Information

5 C. Craig Bonneville Power Administration Fish and Wildlife Division

P.O. Box 3621

Portland, OR 97208

10 J. Laufle

U.S. Army Corps of Engineers Seattle District

EN-PL-ER

P.O. Box C-3755

Seattle, WA 98124

ONSITE

DOE Richland Operations Office

R.W. Hildebrand
No. of

Copies

27 Pacific Northwest Laboratonx

D.K. Shreffler (3)

D.G. Geist (10)

W.V. Mavros (5)

D.D. Dauble

L.M. Gully

Publishing Coordination

Technical Report Files (5)

Bouting

R.M. Ecker

M.J. Graham

P.M. Irving

C.S. Sloane

P.C. Hays - last
SE-UI

K6-54

K6-54

K6-54

SE-UI

Distr. 1 


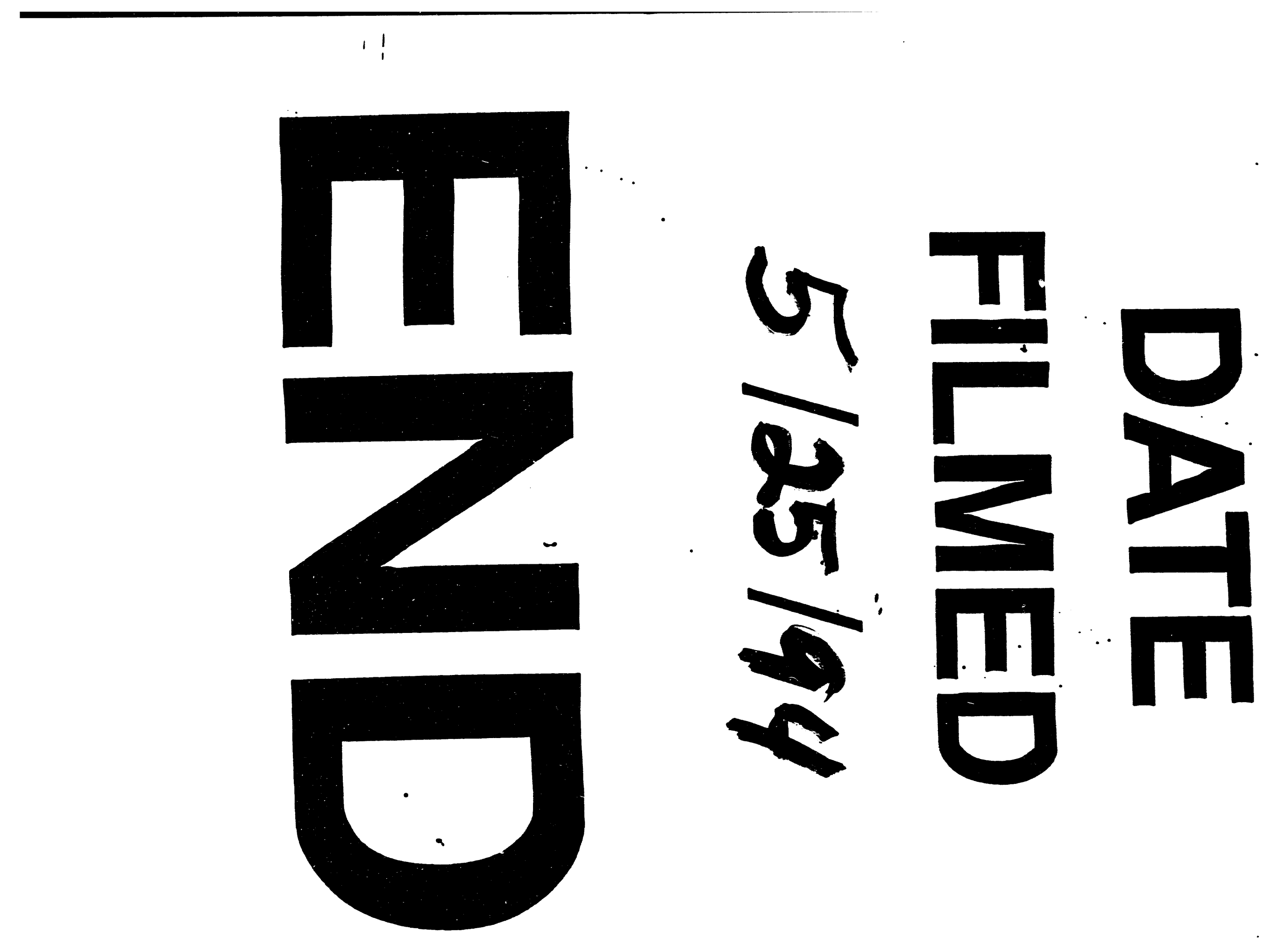


